\title{
Hydroacoustic Evaluation of Juvenile Salmonid Passage at The Dalles Dam Spillway, 2006
}

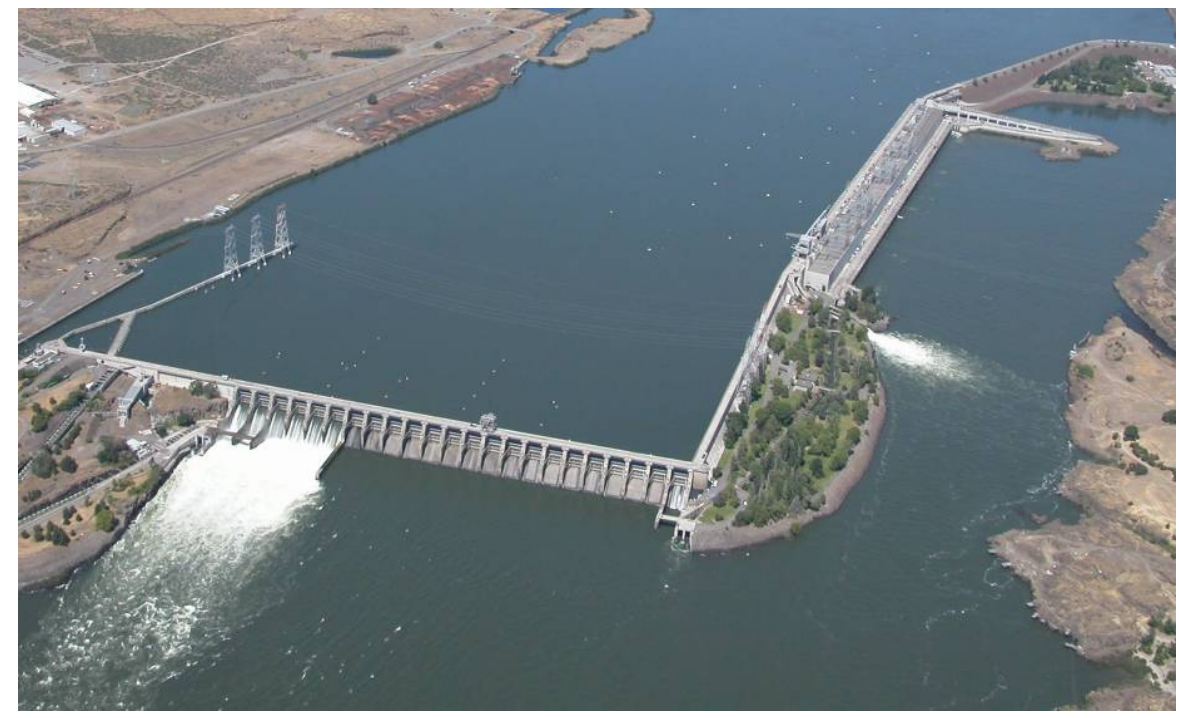

GE Johnson

F Khan

JR Skalski

CL Rakowski

MC Richmond

JA Serkowski

FINAL REPORT

May 24, 2007

Prepared for the U.S. Army Corps of Engineers

Portland District, Portland, Oregon

under a Related Services Agreement

with the U.S. Department of Energy

Contract DE-AC05-76RL01830

\section{Pacific Northwest \\ National Laboratory}

Operated by Battelle for the

U.S. Department of Energy 


\title{
DISCLAIMER
}

This report was prepared as an account of work sponsored by an agency of the United States Government. Neither the United States Government nor any agency thereof, nor Battelle Memorial Institute, nor any of their employees, makes any warranty, express or implied, or assumes any legal liability or responsibility for the accuracy, completeness, or usefulness of any information, apparatus, product, or process disclosed, or represents that its use would not infringe privately owned rights. Reference herein to any specific commercial product, process, or service by trade name, trademark, manufacturer, or otherwise does not necessarily constitute or imply its endorsement, recommendation, or favoring by the United States Government or any agency thereof, or Battelle Memorial Institute. The views and opinions of authors expressed herein do not necessarily state or reflect those of the United States Government or any agency thereof.

\author{
PACIFIC NORTHWEST NATIONAL LABORATORY \\ operated by \\ BATTELLE \\ for the \\ UNITED STATES DEPARTMENT OF ENERGY \\ under Contract DE-AC05-76RL01830
}

\author{
Printed in the United States of America \\ Available to DOE and DOE contractors from the \\ Office of Scientific and Technical Information, \\ P.O. Box 62, Oak Ridge, TN 37831-0062; \\ ph: (865) 576-8401 \\ fax: (865) $576-5728$ \\ email: reports@adonis.osti.gov
}

\begin{abstract}
Available to the public from the National Technical Information Service, U.S. Department of Commerce, 5285 Port Royal Rd., Springfield, VA 22161 ph: (800) 553-6847 fax: (703) 605-6900

email: orders@ntis.fedworld.gov

online ordering: http://www.ntis.gov/ordering.htm
\end{abstract}

This document was printed on recycled paper. $(2 / 2007)$ 


\title{
Hydroacoustic Evaluation of Juvenile Salmonid Passage at The Dalles Dam Spillway, 2006
}

\author{
GE Johnson \\ F Khan \\ JR Skalski ${ }^{\mathrm{a}}$ \\ CL Rakowski \\ MC Richmond \\ JA Serkowski
}

FINAL REPORT

May 24, 2007

Prepared for the U.S. Army Corps of Engineers

Portland District, Portland, Oregon

under a Related Services Agreement

with the U.S. Department of Energy

Contract DE-AC05-76RL01830

Pacific Northwest National Laboratory

P.O. Box 999

Richland, Washington 99352

\footnotetext{
${ }^{a}$ University of Washington, Seattle, Washington
} 



\section{Preface}

This research was conducted under the auspices of the U.S. Army Corps of Engineers, Northwestern Division's Anadromous Fish Evaluation Program (AFEP) to implement the Congressionally-appropriated Columbia River Fish Mitigation Project. The research pertains to AFEP study code SPE-P-00-08 and was funded by the U.S. Army Corps of Engineers Portland District (USACE) under a contract with the Pacific Northwest National Laboratory (PNNL), operated by Battelle for the U.S. Department of Energy. The University of Washington was a subcontractor to PNNL.

\section{Summary}

We evaluated fish passage at The Dalles Dam (TDA) spillway in 2006. The goal of the study was to provide information on smolt passage to inform decisions on long-term measures and operations to improve smolt survival at the dam. The study was part of one of the main avenues of juvenile salmonid passage research at The Dalles Dam -- the Spillway Improvements Study. Survival of downstream migrants passing through the dam's spillway is generally lower than at other projects on the lower Columbia River. To improve the survival of spilled fish, a wall dividing the spillway between Bays 6 and 7 was installed in winter 2003/2004 to eliminate lateral flow in the stilling basin and a bulk spill pattern at Bays 1-6 was instituted in 2004 and beyond. This bulk pattern produces a large vortex at Bay 6 that is hypothesized to entrain juvenile salmonids leading to relatively high passage rates at Bay 6 . Fish passing at Bay 6 are more likely to encounter predators near the islands downstream of the dam than those passing at Bays 1-5.

In 2006, a temporary vortex suppression device (VSD) made of a spillway stop log was installed in Bay 6 for the purpose of a pilot study to re-distribute fish away from Bay 6 to Bays 1-5. The pilot study, however, was terminated after results of a test of the VSD structure in mid-April led dam operators to conclude that the stop log would not be viable structurally as a VSD surrogate during the high discharges (16-20 kcfs) anticipated for Bay 6 in 2006. The USACE did continue to collect baseline data on juvenile salmonid passage distribution in support of any future VSD and spillway passage studies. Accordingly, our study objectives were to 1) estimate fish distributions at the spillway, including daily, vertical, horizontal, intensive, and diel distributions and 2) estimate fish trajectories relative to water velocity vectors.

The study objectives were fulfilled with a combination of hydroacoustic and hydraulic data. We used fixed-location hydroacoustic methods with split-beam transducers deployed at all open bays at the spillway (Bays 1-9 and 14). There was especially intense sampling using multiple transducers at Bays 5 and 6, because these bays are where the USACE was considering VSD deployment. We did not sample fish passage at the powerhouse in 2006. The hydroacoustic passage data were integrated with hydraulic data from a computational fluid dynamics (CFD) model. Fish passage data were collected $24 \mathrm{~h} / \mathrm{d}$ during spring (April 12 to June 4) and summer (June 5 to July 16) study periods in 2006.

During the 2006 study, daily outflow at TDA ranged from 151 to 391 thousand cubic feet per second (kcfs). Mean daily outflow was $325 \mathrm{kcfs}$ in spring and $254 \mathrm{kcfs}$ in summer study periods. Total project outflow was greater than the ten-year average for both the spring and summer study periods, $121 \%$ in 
spring and $103 \%$ in summer. Spill for fish protection commenced on April 10 and was bulked in Bays 16. Daily spill flow during our study ranged from 61 to $217 \mathrm{kcfs}$, with a mean of $123 \mathrm{kcfs}$ in spring and $104 \mathrm{kcfs}$ in summer. Spill was $38 \%$ of total project discharge during spring and $41 \%$ during summer.

Our study encompassed the majority of the migration period for yearling Chinook (Oncorhyncus tshawytscha), coho (O. kisutch), and sockeye (O. nerka) salmon as well as steelhead (O. mykiss) trout and subyearling Chinook salmon. During the spring study period, species composition was yearling Chinook salmon (46\%); steelhead (34\%); sockeye (11\%); coho (6\%), and subyearling Chinook salmon (3\%). Passage of yearling fish peaked in mid to late May. During the summer study period, subyearling Chinook salmon comprised $95 \%$ of the outmigration with the remainder being yearling salmonids (1\%); steelhead (2\%); sockeye (1\%); and coho (1\%). Passage of subyearling Chinook salmon peaked at the end of June and early July.

The main findings, summarized by objective, were as follows:

1. Estimate fish daily passage and vertical, horizontal, intensive, and diel distributions at the spillway.

- There were peaks in daily passage during May and July for yearling and subyearling fishes, respectively.

- $\quad$ The vertical distribution of fish at the spillway during spring was concentrated in the upper portion of the water column in the spring with the majority (20\%) of total estimated fish passing in the top $5 \mathrm{~m}$ of the water column. In contrast, during summer, the majority (25\%) passed at approximately $10-11 \mathrm{~m}$ deep.

- Horizontally, fish passage rates $(\# / \mathrm{h})$ and fish densities $(\# / \mathrm{h} / \mathrm{kcfs})$ were highest at Bay 6 during both spring and summer. The horizontal distribution gradually increased from Bay 1 to Bay 4 , with a major increase at Bay 5 and a peak at Bay 6.

- At Bays 5 and 6, the intensive vertical and horizontal distribution of fish passage was much more variable during spring than summer and more variable at Bay 5 than Bay 6 . At Bay 5, most fish appeared to use the upper portion of the water column and the center of the bay in the spring months and the lower portion of the water column in the summer. Passage in Bay 6 was intensified in the lower portion of the water column and center of the bay in the spring, whereas in the summer months, fish appeared to use the uppermost portion of the water column.

- The diel distribution of fish passage at the spillway was much more variable during spring than summer. During both periods (spring and summer), passage peaked in the early to mid morning hours and was lowest during the afternoon hours $(1300-1800 \mathrm{~h})$.

2. Estimate fish trajectories relative to water velocity vector.

- Fish trajectories obtained from the split-beam hydroacoustic data closely matched the water velocity vectors from the CFD model. Fish velocity was slower than water velocity immediately above the ogee, indicating fish were oriented upstream and swimming against the flow. Trajectories and water velocities were similar among bays. 


\section{Acknowledgments}

We gratefully acknowledge contributions to this study by

- Honald Crane Services - Bob Austin and Mike Honald;

- $\quad$ PNNL staff - Kyle Bouchard, Dennis Dauble, Eric Fischer, Al Garcia, David Geist, Terri Gilbride, James Hughes, Kathy Lavender, Gene Ploskey, Kathi Ruiz, Mark Weiland, and Shon Zimmerman;

- Schlosser Machine Shop - Vincent Schlosser;

- $\quad$ U.S. Army Corps of Engineers fisheries biologists - Bob Cordie, Bernard Klatte, Mike Langeslay, Bob Wertheimer, and Miro Zyndol;

- U.S. Army Corps of Engineers personnel - Dick Harrison, Norm Tolonen, and Art Kunigel and the structural crew;

- University of Washington, Columbia Basin Research - Cindy Helfrich and Jim Lady. 
Hydroacoustic Evaluation of Juvenile Salmonid Passage at The Dalles Dam Spillway, 2006 


\section{Contents}

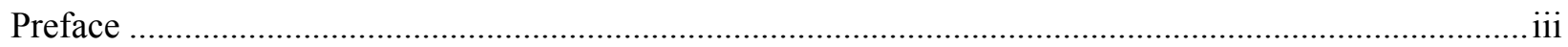

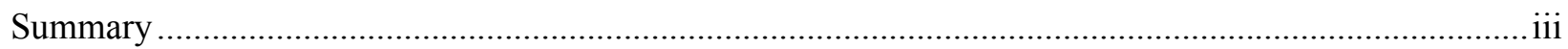

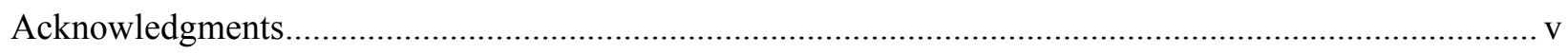

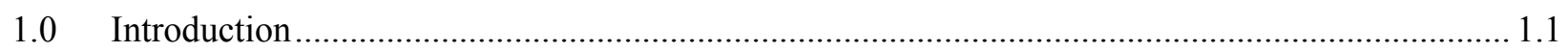

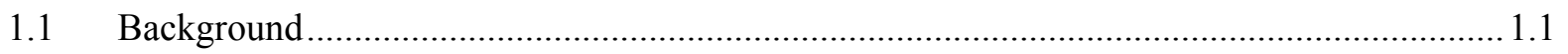

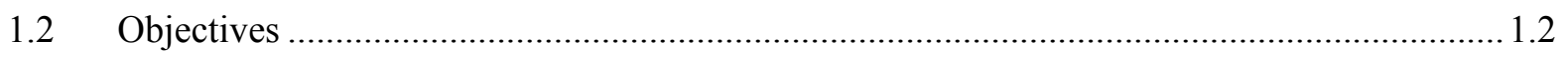

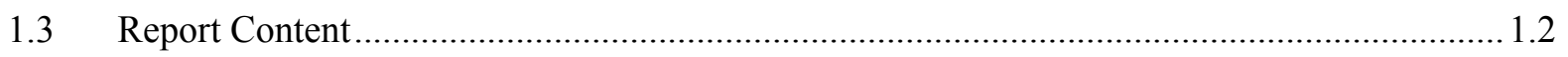

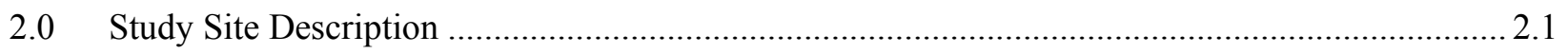

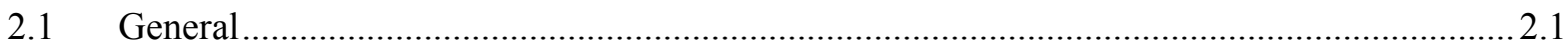

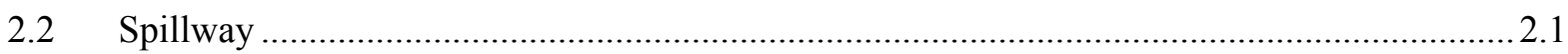

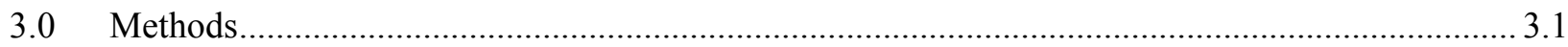

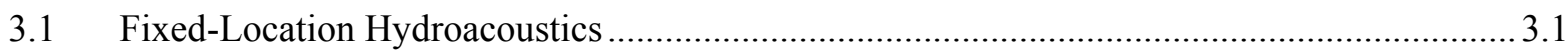

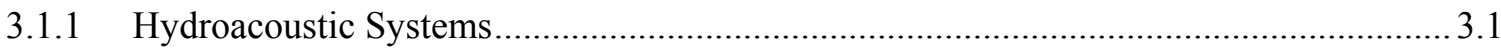

3.1.2 Transducer Locations and Orientations ...................................................................... 3.1

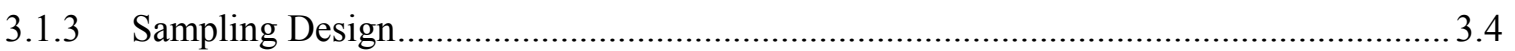

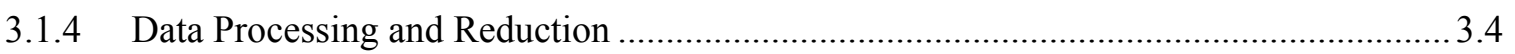

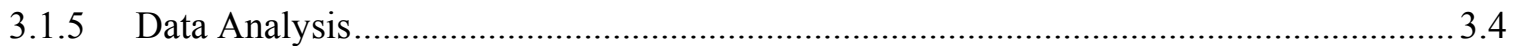

3.2 Computational Fluid Dynamics Model.................................................................................... 3.4

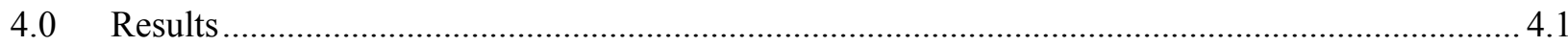

4.1 Biological and Environmental Conditions ........................................................................ 4.1

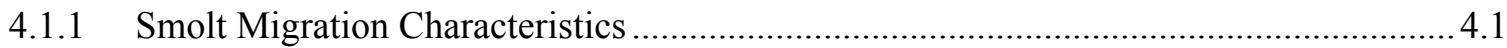

4.1.2 River Discharge, Spill Operations, Forebay Elevation, and Temperature ....................... 4.2

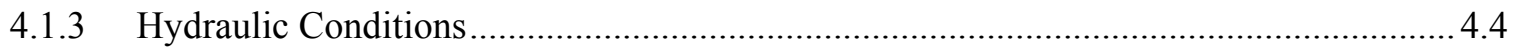

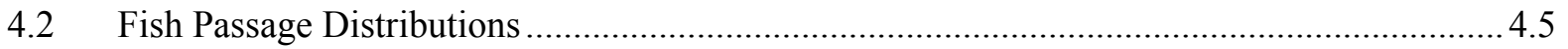

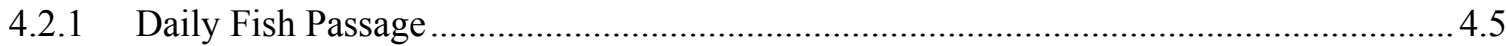

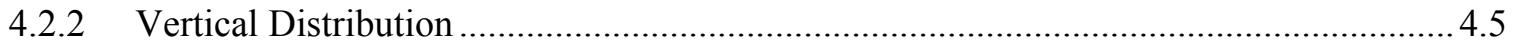

4.2.3 Horizontal Distribution: Passage and Density ….......................................................... 4.9

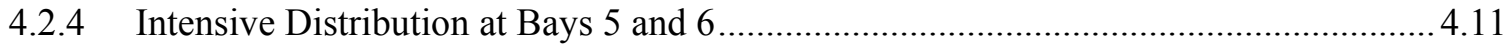

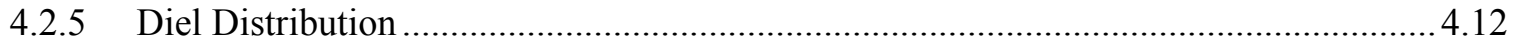

$4.3 \quad$ Fish Trajectories Relative to Water Velocity...................................................................... 4.13

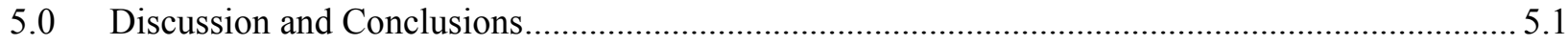

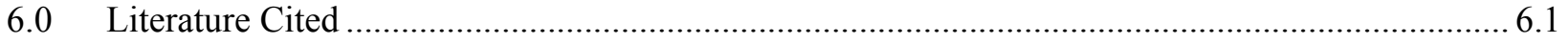


Hydroacoustic Evaluation of Juvenile Salmonid Passage at The Dalles Dam Spillway, 2006

Appendix A: Statistical Synopsis for The Dalles Spillway Hydroacoustic Evaluations in 2006 A.1

Appendix B: Spatial Expansions. B.1 


\section{Figures}

Figure 1.1. Aerial Photograph of The Dalles Dam .................................................................................. 1.1

Figure 2.1. Plan View of The Dalles Dam Showing Forebay Bathymetry..........................................2.1

Figure 2.2. Isometric View Showing a Computer Generated Image from a CFD Model

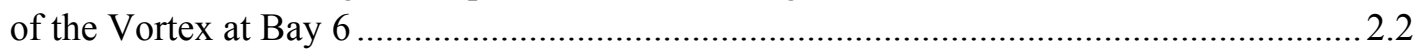

Figure 2.3. Plan View Showing a Computer Generated Image from a CFD Model of

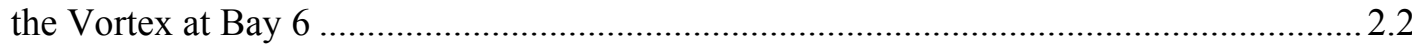

Figure 3.1. Plan View Showing Transducer Locations at The Dalles Dam Spillway, 2006 ....................3.2

Figure 3.2. Cross-Sectional View of Transducer Deployments for Bays 1-5, 7-9, and 14 and Bay 6......3.3

Figure 3.3. Plan View of the Side-Looking Transducer in Front of Bay 6 .......................................... 3.3

Figure 4.1. Smolt Monitoring Program's Passage Index for April 12 - July 16, 2006,

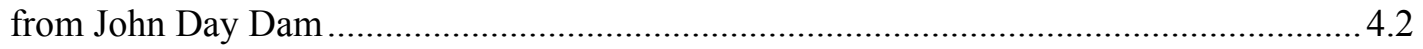

Figure 4.2. Daily Total Outflow and Spill for the 2006 Study Period and the 10-yr Average ................ 4.2

Figure 4.3. Mean Discharge by Spill Bay during Spring and Summer 2006 at The Dalles Dam............ 4.3

Figure 4.4. Mean Daily Forebay Elevation at The Dalles Dam during the 2006 Study Period................ 4.3

Figure 4.5. Mean Daily Temperature at The Dalles Dam during the 2006 Study Period........................ 4.3

Figure 4.6. Plan View of Spillway Forebay Water Velocities from Elevation $130 \mathrm{ft}$ for Case 1 ............4.4

Figure 4.7. Plan View of Spillway Forebay Water Velocities from Elevation $150 \mathrm{ft}$ for Case 1 ............4.4

Figure 4.8. Plan View of Spillway Forebay Water Velocities at Bays 1 - 6, from Elevation $130 \mathrm{ft}$

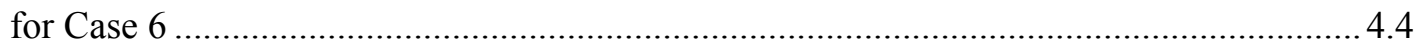

Figure 4.9. Plan View of Spillway Forebay Water Velocities at Bays 1 - 6, from Elevation $150 \mathrm{ft}$ for Case 6

Figure 4.10. Fish Passage Indices for The Dalles Dam, 2006 ......................................................... 4.5

Figure 4.11. Vertical Distributions by Time Period at all Sampled Bays Combined at The Dalles Dam Spillway, 2006

Figure 4.12. Vertical Distributions by Bay for the Entire Study Period Combined at The Dalles Dam Spillway, 2006

Figure 4.13. Vertical Distributions by Bay by Two-Week Time Period at The Dalles Dam Spillway, 2006.

Figure 4.14. Horizontal Distributions of Fish Passage Rates (number per hour) by Time Period at The Dalles Dam Spillway, 2006

Figure 4.15. Horizontal Distributions of Fish Density by Time Period at The Dalles Dam Spillway, 2006 
Figure 4.16. Intensive Distributions Vertically and Horizontally at Bays 5 and 6 by Time Period at The Dalles Dam Spillway, 2006

Figure 4.17. Diel Distribution for All Bays Combined at the Spillway by Time Period at The Dalles Dam Spillway, 2006

Figure 4.18. Fish Trajectories and Water Velocity Vectors by Bay for the Entire Study Period Combined at The Dalles Dam Spillway, 2006

\section{Tables}

Table 3.1. Spill Bay Sample Locations and Number of Transducers at The Dalles Dam, 2006 .............. 3.2

Table 3.2. Cases for CFD Modeling of The Dalles Dam Forebay, 2006............................................... 3.5 


\subsection{Introduction}

Development of long-term measures to protect juvenile salmon at The Dalles Dam (Figure 1.1) is a high priority in the endeavor to increase salmon smolt survival through the Federal Columbia River Power System (FCRPS). Juvenile salmon pass The Dalles Dam (TDA) through one of three routes: turbines, sluiceway, or spillway. For future salmonid passage improvements at The Dalles Dam, the U.S. Army Corps of Engineers Portland District (USACE) is currently developing a Configuration and Operation Plan. Ploskey et al. (2001) and Johnson et al. (2007) synthesized fish passage studies at The Dalles Dam during 1982-2000 and 2001-2005, respectively.

In 2006, the USACE contracted Pacific Northwest National Laboratory (PNNL) to evaluate fish passage via The Dalles Dam spillway. The goal of the study was to provide information on spillway fish passage to inform decisions on long-term measures and operations to improve smolt survival at the dam.

\subsection{Background}

The multi-faceted strategy to improve smolt survival at The Dalles Dam involves all three types of passage routes at the project: turbines, sluiceway, and spillway. At the turbines, intake occlusions were tested in 2001 and 2002 to determine if blocking the upper half of the turbine intake trash racks might significantly reduce turbine entrainment. Results indicated that the occlusions were generally not effective at reducing turbine passage (Johnson et al. 2003; Hausmann et al. 2004). To divert juvenile salmonids from the turbines to the spillway, bioengineering was undertaken to design a floating wall in the forebay. This fish protection strategy, which applied results from forebay distribution and migration pathway studies by Cash et al. (2005) and Faber et al. (2005), remains under consideration. At the sluiceway, alternative means of operating the entrance gates were investigated in 2004 and 2005 to provide additional protection for juvenile salmonids at the TDA powerhouse (Johnson et al. 2005, 2006; Hansel et al. 2005, 2007). These studies resulted in a new sluiceway operation with six open gates at the west and middle portions of the powerhouse to pass juvenile salmonids. At the spillway, the USACE is implementing the Spillway Improvements Study.

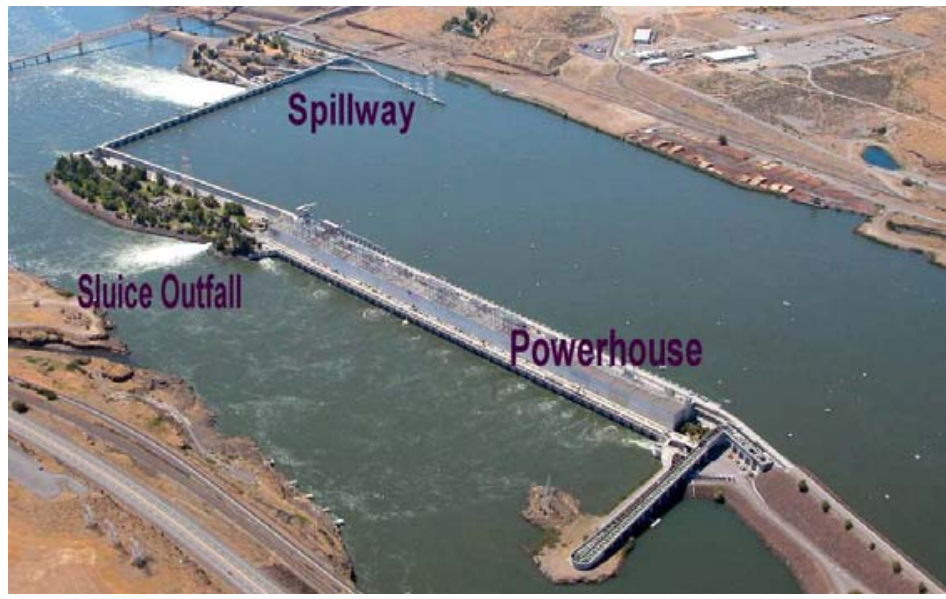

Figure 1.1. Aerial Photograph of The Dalles Dam. Flow is from right to left. (Photograph courtesy of D. Feil, USACE.) 
Survival of downstream migrants at The Dalles Dam spillway is generally lower than at other projects on the lower Columbia River (Ploskey et al. 2001; Johnson et al. 2007). To improve the survival of spilled fish, a wall dividing the spillway between Bays 6 and 7 was installed in winter 2003/2004 to eliminate lateral flow in the stilling basin and a bulk spill pattern at Bays 1-6 was instituted in 2004 and beyond. This bulk pattern produces a large vortex at Bay 6 that is hypothesized to entrain juvenile salmonids leading to relatively high passage rates at Bay 6 . Fish passing at Bay 6 are more likely to encounter predators near the islands downstream of the dam than those passing at Bays 1-5.

In 2006, a temporary vortex suppression device (VSD) was installed in Bay 6 for the purpose of a pilot study. A spill bay stop log served as a surrogate VSD. A multi-disciplinary evaluation with fixed hydroacoustics (this study), radio telemetry, balloon tags, Sensor Fish, and computational fluid dynamics and physical scale modeling was designed. However, results of a test of the VSD structure in mid-April led dam operators to conclude that a stop log would not be a suitable VSD test structure because of concerns about its structural integrity during high discharges (16-20 kcfs) anticipated for Bay 6 during 2006. The USACE continued without the surrogate VSD to collect baseline data for any future VSD or other spillway evaluations. The juvenile salmonid passage distribution data reported here are fundamental to developing the spillway improvements intended to increase juvenile salmonid survival.

\subsection{Objectives}

This study provides information on juvenile salmonid passage at The Dalles Dam that can be used by the USACE, fisheries resource managers, and others to make decisions on long-term measures to enhance spillway passage. The 2006 study was divided into spring (April 12 to June 4) and summer (June 5 to July 16) periods based on the predominance of subyearling Chinook salmon (Oncorhyncus tshawytscha). The research objectives of the 96-d study of juvenile salmonid passage characteristics at The Dalles Dam spillway were to estimate:

1. Passage distributions:
a. daily;
b. vertical;
c. horizontal;
d. intensive at bays 5 and 6 ;
e. diel.

2. Fish trajectories relative to water velocity vectors.

\subsection{Report Content}

This report has six sections and two appendices. Following the introduction in Section 1, the study site is described in Section 2. Section 3 contains the study methods. Section 4 has the results and Section 5 contains discussion and conclusions. Section 6 lists the literature we cited. Appendix A contains a synopsis of the statistical methods. Appendix B presents the equations used to calculate the spatial expansions. 


\subsection{Study Site Description}

\subsection{General}

The Dalles Dam (Figure 1.1) is located at river mile 192 on the Columbia River. It is the second closest dam to the Pacific Ocean in the Federal Columbia River Power System. Full pool elevation is rated at $160 \mathrm{ft}$ above mean sea level (MSL; all elevations hereafter are referenced to MSL).

Minimum operating pool elevation is $155 \mathrm{ft}$. The forebay elevation averages approximately $158 \mathrm{ft}$. The thalweg intersects the dam at the eastern end of the powerhouse and, although there are deep areas immediately in front of the powerhouse (Figure 2.1), much of the forebay is relatively shallow $(<65 \mathrm{ft}$ deep).

The Dalles Dam has a 2,090-ft-long powerhouse with 22 turbine units (called "Main Units" or MU), a total generating capacity of 1,800 megawatts, and a total powerhouse hydraulic capacity of $330 \mathrm{kcfs}$. The powerhouse also has two small turbine units, called the fish units, at the west end that provide attraction flow to the fish ladder for upstream migrant adult salmonids. The face of the powerhouse is $11.3^{\circ}$ off vertical. At the trash racks, the turbine intake ceiling and floor are at elevations $141 \mathrm{ft}$ and $57 \mathrm{ft}$, respectively. An ice and trash sluiceway spanning the entire powerhouse is used to pass juvenile salmonids in about 4,500 cfs through six open gates from April through November each year.

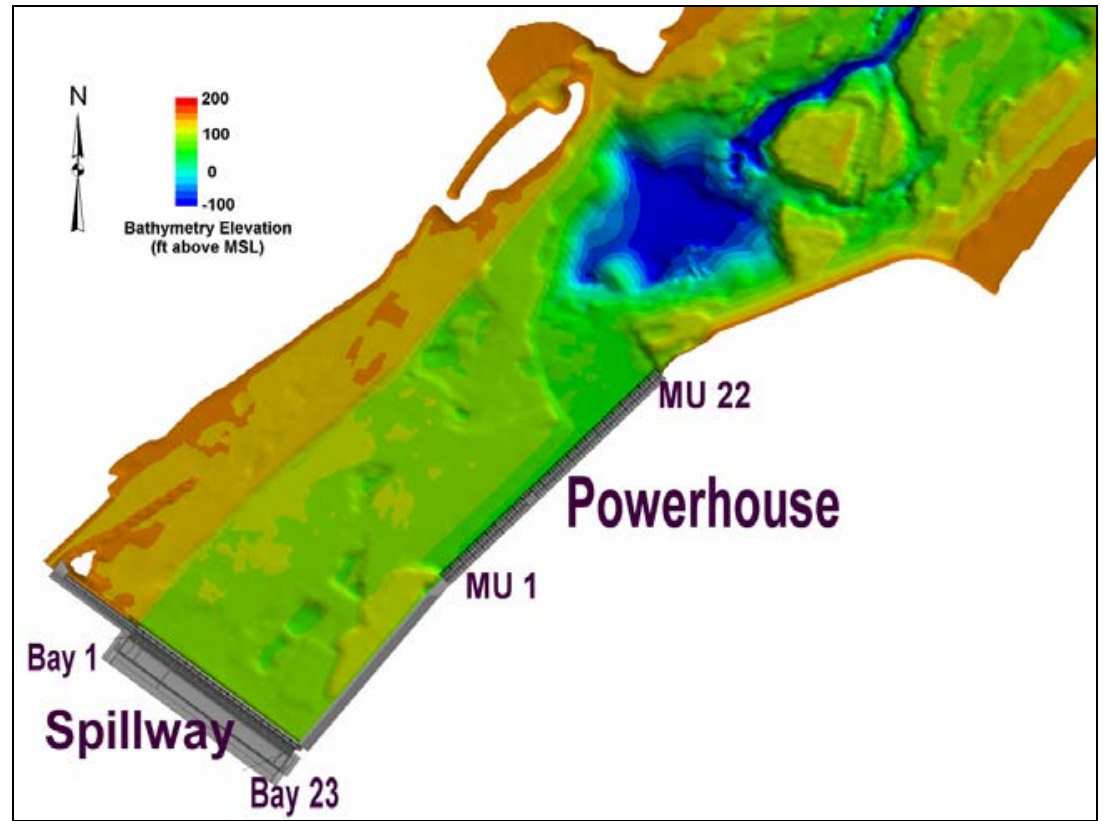

Figure 2.1. Plan View of The Dalles Dam Showing Forebay Bathymetry. Flow is from right to left.

\subsection{Spillway}

The 1,380-ft-long spillway is comprised of 23 bays with Tainter (radial) gates $50 \mathrm{ft}$ wide. A concrete wall (10 ft wide, $43 \mathrm{ft}$ high, $193 \mathrm{ft}$ long) was constructed in the stilling basin between Bays 6 and 7 during the winter of 2003-2004. The purpose of this "spillwall" is to stop the lateral movement of water and fish across the stilling basin, thereby improving smolt survival by reducing residence 
time and exposure to predators and adverse hydraulic conditions in the stilling basin. With the spillwall in place, a new spill pattern was designed to place the bulk of spill discharge through Bays 1-6 on the northern side of the forebay to improve egress conditions and, hence, survival rates.

During bulked spill, vortices ${ }^{(a)}$ of varying degrees form off the forebay pier noses at one or both sides of each open spill bay. The vortices in Bays 2, 3, 4, and 5 are relatively small; however, large vortices develop in the end bays, Bays 1 and 6 . One large vortex is located on the north side of Bay 1 and another is located on the south side of Bay 6. The vortex in Bay 6 (Figures 2.2 and 2.3) is a major concern because it is believed this vortex may be indirectly related to the injury and predation of juvenile salmonids in areas downstream of the dam.

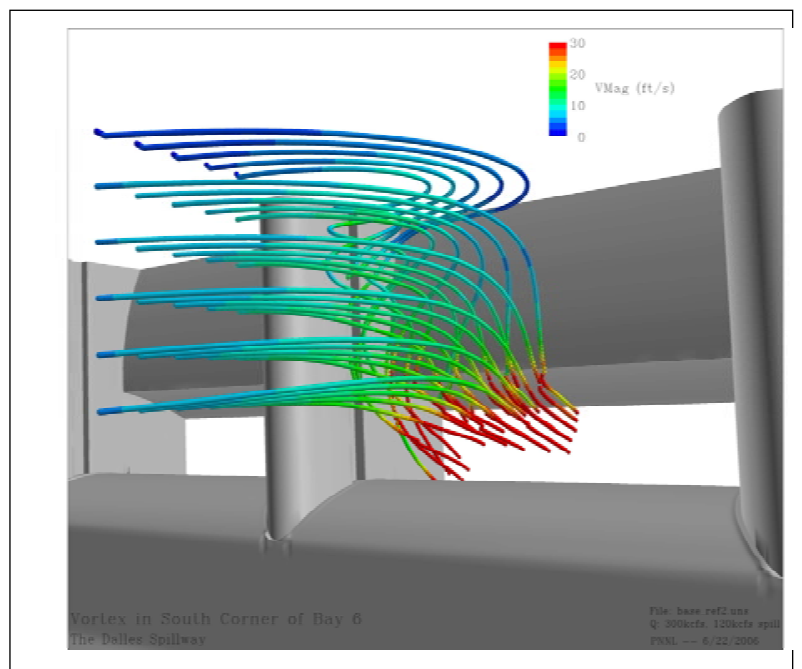

Figure 2.2. Isometric View Showing a Computer Generated Image from a CFD Model of the Vortex at Bay 6. (Graphic is from Deng et al. 2006.)

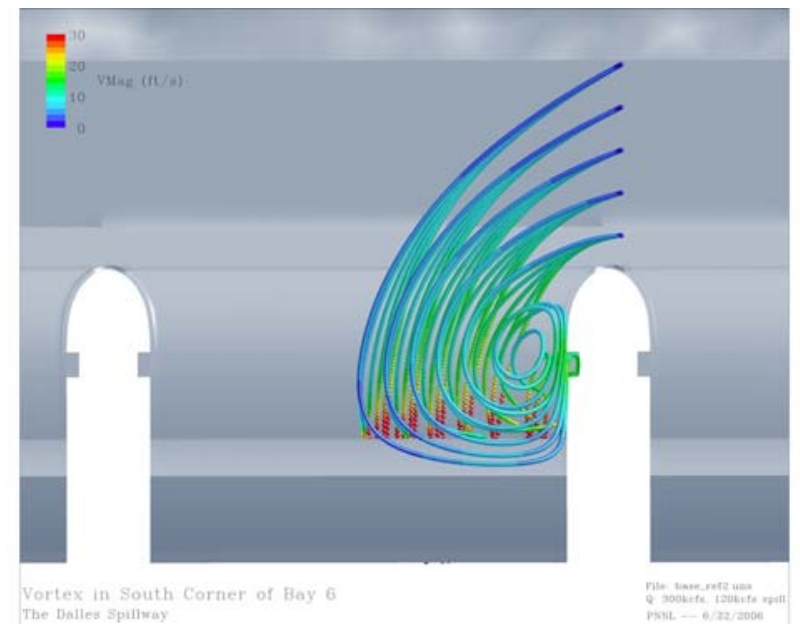

Figure 2.3. Plan View Showing a Computer Generated Image from a CFD Model of the Vortex at Bay 6. Flow is from top to bottom of the figure. Streamlines were seeded in the forebay off of the Bay 6/7 pier nose. (Graphic is from Deng et al. 2006.)

a According to Vischer and Hager (1998, p. 221), "A vortex is a cohert structure of rotational flow. It is mainly caused by eccentricity of the approach flow to a hydraulic sink, but asymmetric approach flow conditions and obstruction effects can also set up vortices." 


\subsection{Methods}

The methods section includes descriptions of the hydroacoustic technique and hydraulic approach. We collected fish passage data using fixed-location hydroacoustics. We obtained hydraulic data from a computational fluid dynamics (CFD) model.

\subsection{Fixed-Location Hydroacoustics}

The fixed-location hydroacoustic technique was employed to accomplish Objectives 1 and 2 of this study. This technique, conceived by Carlson et al. (1981) for single-beam acoustic systems, is described by Thorne and Johnson (1993). In addition to single-beam, split-beam technology is now an important element of fixed-location hydroacoustics. The split-beam technique is explained by MacLennan and Simmonds (1992). The methods used in 2006 were similar to those employed in the 2001, 2002, and 2004 hydroacoustic studies at The Dalles Dam (Moursund et al. 2002; Johnson et al. 2003; Johnson et al. 2005).

The general approach was to deploy split-beam transducers to sample fish and apply the acoustic screen model (Johnson 2000) to estimate fish passage rates and distributions at the spillway. Splitbeam transducers provided data to determine weighting factors, assess assumptions of the model, and determine the magnitude of any biases. Split-beam data were used to estimate the average backscattering cross section of fish for detectability modeling and the direction of fish travel through sampling volumes to assess the assumptions of the acoustic screen model. Transducer sampling volumes were positioned to minimize ambiguity in ultimate fish passage routes and the potential for multiple detections of the same fish.

\subsubsection{Hydroacoustic Systems}

Data collection involved five Precision Acoustic Systems (PAS) split-beam hydroacoustic systems. All systems operated at $420 \mathrm{kHz}$. The data collection systems had Harp-SB (split beam) Data Acquisition/Signal Processing software installed on a personal computer controlling a PAS-103 Multi-Mode Scientific Sounder. The PAS-103 sounders controlled transducers deployed in spill bays. A total of 18 six-degree split-beam transducers were installed in Bays 1-9 and 14 (Table 3.1). Bays 10, 11, 12, and 13 were not opened in 2006. All systems used a $-56 \mathrm{~dB}$ (re: $1 \mu$ pa at $1 \mathrm{~m}$ ) voltage output threshold. Echo sounder transmission rates were $30 \mathrm{pps}$ (pings per sec).

\subsubsection{Transducer Locations and Orientations}

Transducer locations are depicted in Figure 3.1. Each transducer was randomly placed in either a north $(\mathrm{N})$, north center $(\mathrm{NC})$, center $(\mathrm{C})$, south center (SC) or south (S) location of each bay. Except for Bay 6, transducers were attached to pole mounts and deployed under deck plates. Each transducer was placed approximately $5 \mathrm{ft}$ below the surface (transducer at elevation $153 \mathrm{ft}$ ) and aimed downward and downstream at a $8^{\circ}$ angle off vertical (Figure 3.2). 
Table 3.1. Spill Bay Sample Locations and Number of Transducers at The Dalles Dam, 2006

\begin{tabular}{ccc}
\hline Spill Bay & Sample Locations & Number of Transducers \\
\hline 1 & $1 \mathrm{C}$ & 1 \\
2 & $2 \mathrm{NC}$ & 1 \\
3 & $3 \mathrm{C}, 3 \mathrm{SC}$ & 2 \\
4 & $4 \mathrm{NC}, 4 \mathrm{SC}$ & 2 \\
5 & $5 \mathrm{~N}, 5 \mathrm{NC}, 5 \mathrm{C}, 5 \mathrm{SC}$ & 4 \\
6 & $6 \mathrm{~N}, 6 \mathrm{NC}, 6 \mathrm{C}$ & 3 \\
7 & $7 \mathrm{C}$ & 1 \\
8 & $8 \mathrm{C}$ & 1 \\
9 & $9 \mathrm{NC}$ & 1 \\
14 & $14 \mathrm{C}$ & 1 \\
$6 / 7$ & Side looker & 1 \\
\hline Total & & 18 \\
\hline
\end{tabular}

At Bay 6, transducers were attached to poles and mounted over the forebay parapet wall because we anticipated the USACE would have a vortex suppression device in Bay 6 . Bay 6 transducers were placed approximately $4 \mathrm{ft}$ below the surface (transducer at elevation $153 \mathrm{ft}$ ) and aimed downward and downstream at a $27^{\circ}$ angle off vertical.

To quantify the distribution of fish in the forebay of Spill Bay 6 to extrapolate data from the downlookers at Bay 6 across the entire bay (see Appendix A for details), a side-looking transducer was installed on the pier nose between Bays 7 and 8 (Figure 3.3). For safety reasons, this transducer was installed on July 1 after the USACE ceased spilling from Bays 7, 8 and 9. The side looker was used during July $1-16,2006$. The transducer was attached to a pole and mounted over the parapet wall adjacent (north side) to the pier nose and placed $15 \mathrm{ft}$ below the surface, angled $8^{\circ}$ down, and aimed across Bay 7 to Bay 6. It sampled across the southern two-thirds across the forebay immediately in front of Bay 6 before beam-spreading resulted in interference from the water surface.

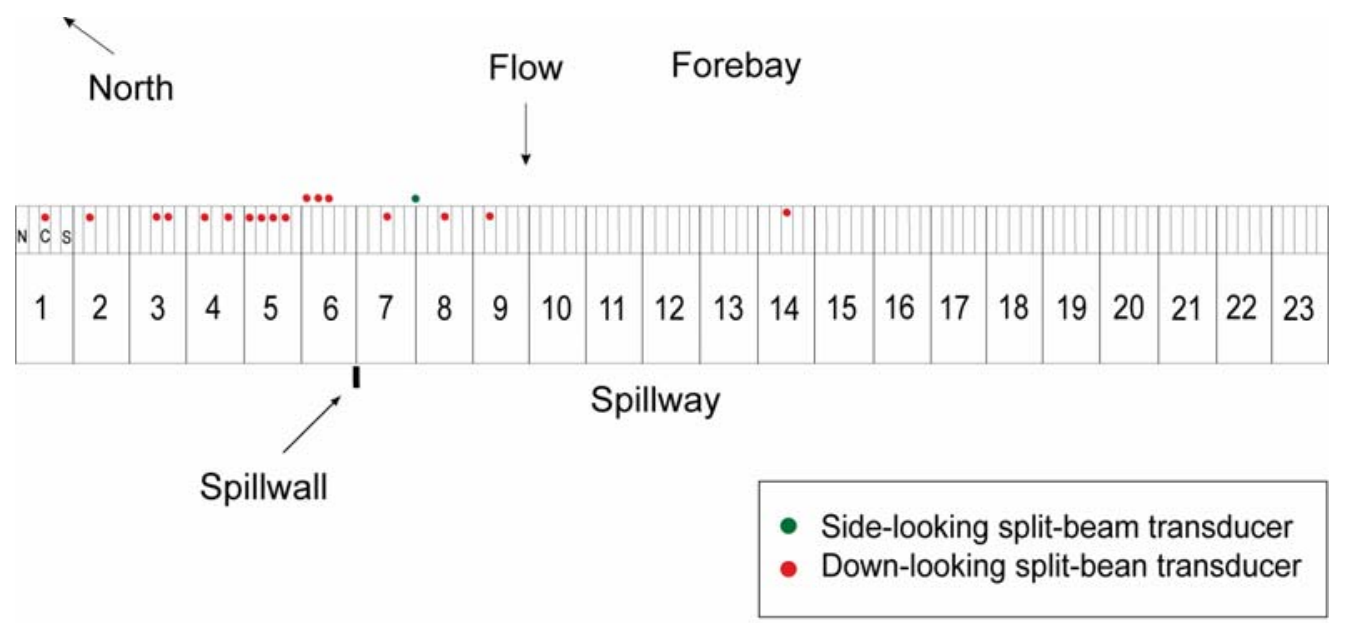

Figure 3.1. Plan View Showing Transducer Locations at The Dalles Dam Spillway, 2006 

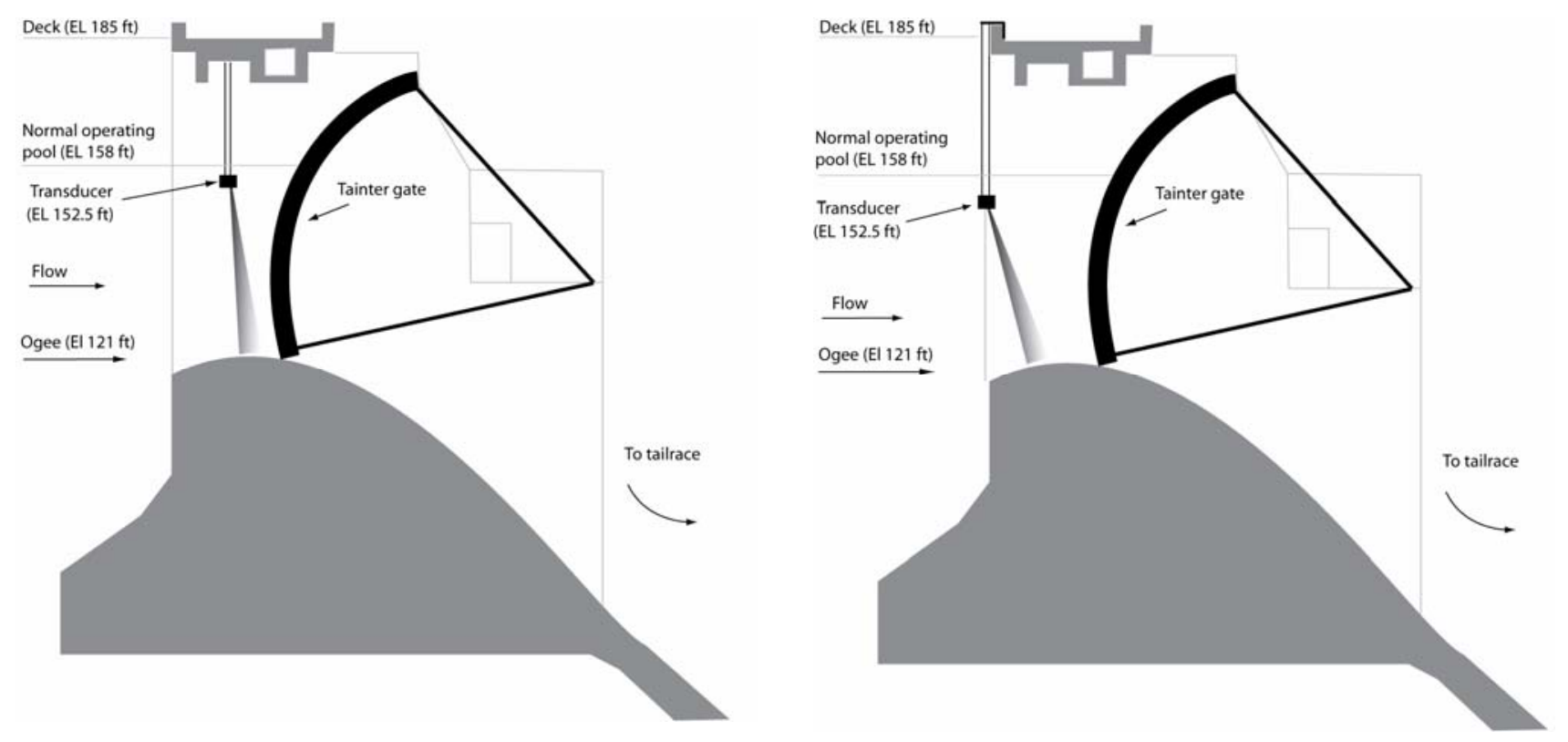

Figure 3.2. Cross-Sectional View of Transducer Deployments for Bays 1-5, 7-9, and 14 (left) and Bay 6 (right)

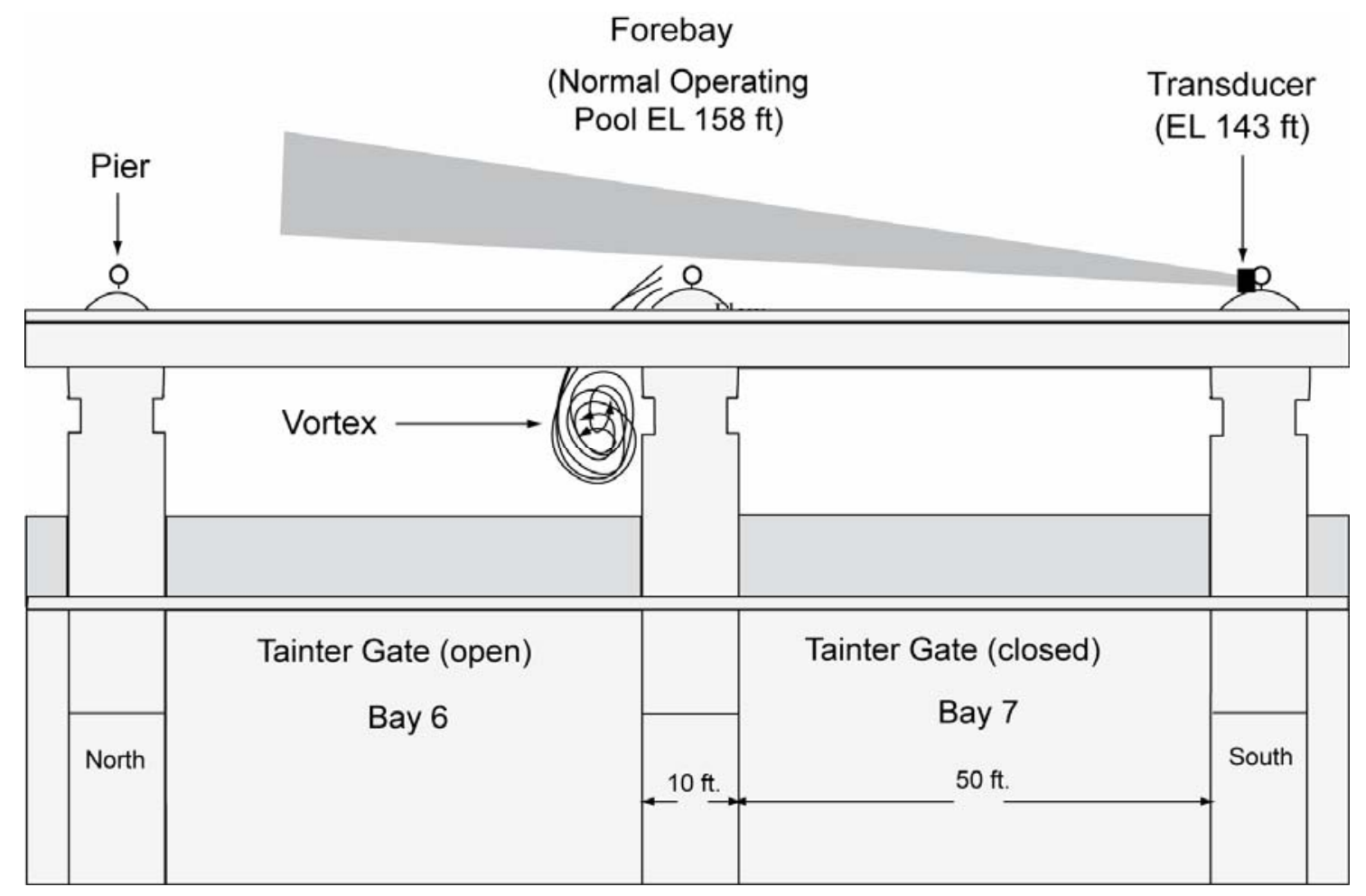

Figure 3.3. Plan View of the Side-Looking Transducer in Front of Bay 6. The lines to the left of the Bay 6/7 pier represent the Bay 6 vortex. 


\subsubsection{Sampling Design}

Samples were collected systematically, i.e., same order among sampling locations each hour, at 1min intervals $24 \mathrm{~h} / \mathrm{d}$. The order the transducers were sampled was randomized at the beginning of the study then kept in place for the duration. Each location was sampled 15 to 20 times per hour depending on the number of transducers connected to a particular sounder.

\subsubsection{Data Processing and Reduction}

After the acoustic echo data were collected and archived at the field site, they were processed to extract fish tracks. At this stage in the analysis, we were careful to set the tracking parameters to include all fish at the expense of including spurious tracks. Next, to separate acceptable from unacceptable tracks, we filtered using fish track characteristics such as slope and pulse width. This data processing and reduction process was similar to that used by Johnson et al. (2006).

\subsubsection{Data Analysis}

The process we used to estimate passage rates from filtered tracked fish is explained in detail in Appendix A. Briefly, each fish track that survived the filtering process was weighted spatially to account for the sample width of the acoustic beam at the target's mid-range relative to the width of the passage route (Appendix B). At all bays except Bay 6, fish passage at unsampled portions of the bay was estimated by extrapolating from the sampled areas. At Bay 6 , we used the horizontal distribution data from the side-looker that sampled in front of both unsampled and sampled areas to estimate total passage for the bay (see Appendix A for a detailed explanation). The sum of these weighted fish was then extrapolated temporally by the hourly sampling fraction (60/total hourly sample time per location). The variances associated with each passage rate estimate were likely underestimates because between-intake variability in passage within a given turbine unit could not be accounted for because of sampling limitations. Ninety-five percent confidence intervals $(C I)$ were calculated as follows:

$$
C I= \pm 1.96 * \sqrt{\text { Variance }}
$$

The passage rate data were used to estimate various performance metrics, including fish passage distribution at the spillway. Equations for each estimator are contained in Appendix A.

\subsection{Computational Fluid Dynamics Model}

A CFD model of The Dalles Dam forebay was used to simulate the hydraulic conditions for various operational scenarios. The model runs were integrated with biological studies on the passage of juvenile salmonids. The computational mesh used for these simulations was created for the USACE by ENSR (Redmond, WA) and PNNL (Richland, WA). For this study, the mesh was rotated and translated onto the State Plane feet, Oregon North geographic coordinate system. The Dalles Dam forebay CFD model included flows from individual Spill Bays 1 though 6. The model was composed of 803,000 fluid cells and a total of 1,090,821 cells. All simulations used STAR-CD, a commercial CFD solver. A given model run took about 3.5 hours to run on a $2.2-\mathrm{GHz}$ dual processor Linux desktop with 4 GB of memory. 
The CFD model was applied to six scenarios representing spring and summer 2006 flows (Table 3.2). We obtained mean total discharges for the spillway and turbines, then made a spreadsheet and allocated the discharges by location according to the patterns from a frequency of occurrence analysis of dam operations.

Table 3.2. Cases for CFD Modeling of The Dalles Dam Forebay, 2006. Forebay elevation was set at $157.8 \mathrm{ft}$. Discharge (Q) is in cubic feet per second.

\begin{tabular}{lrrrrrr}
\hline & Case 1 & Case 2 & Case 3 & Case 4 & Case 5 & Case 6 \\
\hline Powerhouse Q & 211,800 & 187,800 & 171,000 & 158,400 & 144,900 & 120,600 \\
Sluiceway Q & 4,500 & 4,500 & 4,500 & 4,500 & 4,500 & 4,500 \\
Spillway Q & 144,200 & 128,200 & 117,000 & 108,600 & 99,600 & 83,400 \\
Total River Q & 360,500 & 320,500 & 292,500 & 271,500 & 249,000 & 208,500 \\
\hline
\end{tabular}


Hydroacoustic Evaluation of Juvenile Salmonid Passage at The Dalles Dam Spillway, 2006 


\subsection{Results}

The results from the hydroacoustic study at The Dalles Dam spillway in 2006 are organized into three sections: biological and environmental conditions, fish passage distributions (Objective 1), and fish trajectories relative to water velocity (Objective 2).

\subsection{Biological and Environmental Conditions}

This section contains a description of the biological and environmental conditions during the study in 2006, including smolt migration characteristics, river discharge, and hydraulics.

\subsubsection{Smolt Migration Characteristics}

Since juvenile salmonid monitoring is not conducted at The Dalles Dam, data on smolt migration characteristics there are based on the Smolt Monitoring Program's (SMP) sampling at John Day Dam and information on hatchery releases in the Deschutes River drainage. John Day Dam is the nearest upstream dam with smolt monitoring facilities. It is generally representative of species composition and run timing at The Dalles Dam because the travel time from John Day Dam to The Dalles Dam is about $1 \mathrm{~d}$ based on radio telemetry data (Johnson et al. 2007). There is only one significant tributary between the two dams, the Deschutes River. This tributary has a juvenile salmonid migration that includes the release of upwards of 1 million hatchery yearling Chinook salmon each spring. Overall at The Dalles Dam, yearling Chinook salmon and steelhead dominate the downstream migration during spring, while subyearling Chinook salmon dominate the run during summer.

Our study encompassed the majority of the migration period for yearling (stream-type) Chinook (Oncorhyncus tshawytscha), coho (O. kisutch), and sockeye (O. nerka) salmon as well as steelhead (O. mykiss) and subyearling (ocean-type) Chinook salmon. Passage of yearling fish peaked in mid- to late May (Figure 4.1). Passage of subyearling Chinook salmon, the most abundant salmonid fish migrating downstream through John Day Dam, peaked at the end of June and early July. During the spring study period (April 12 to June 4), species composition was

- yearling Chinook salmon (46\%);

- $\quad$ steelhead (34\%);

- $\quad$ coho $(6 \%)$;

- $\quad$ sockeye $(11 \%)$;

- subyearling Chinook salmon (3\%).

During the summer study period (June 5 to July 16), subyearling Chinook salmon comprised 95\% of the outmigration with the remainder being yearling Chinook salmon (1\%); steelhead (2\%); sockeye (1\%); and coho (1\%). Passage of subyearling Chinook salmon peaked at the end of June and early July (Figure 4.1). 


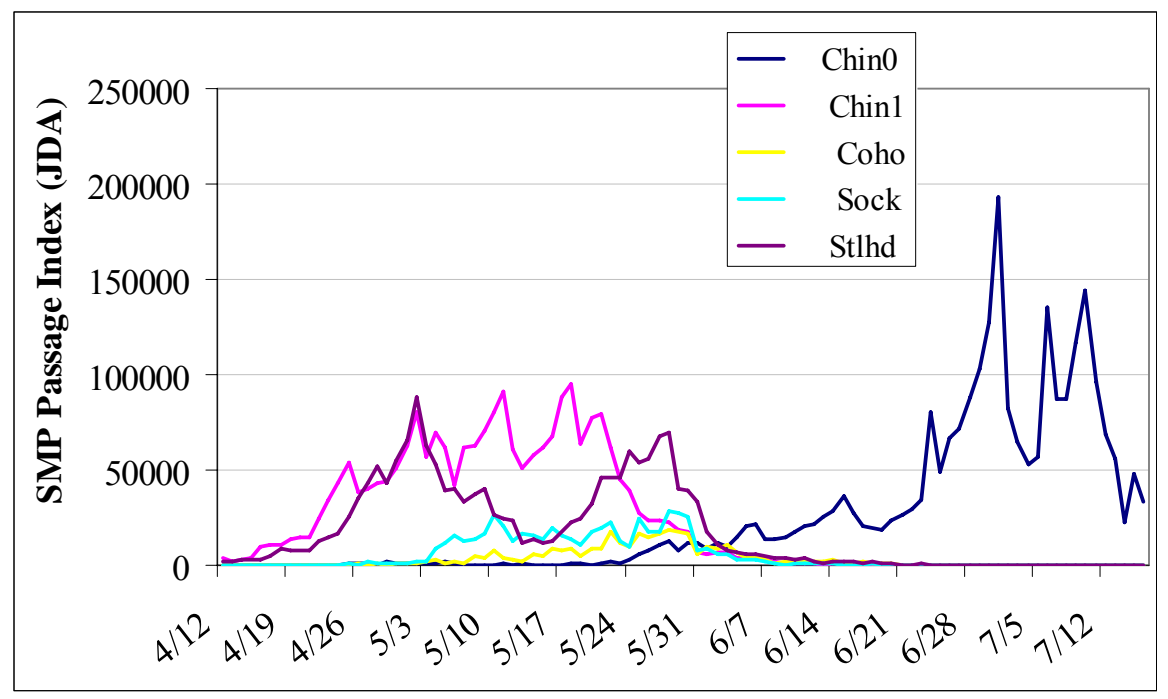

Figure 4.1. Smolt Monitoring Program's Passage Index for April 12 - July 16, 2006, from John Day Dam. Designations in the legend are for subyearling Chinook salmon (Chin0), yearling Chinook salmon (Chin1), coho salmon (Coho), sockeye salmon (Sock), and steelhead (Stlhd). (Data were obtained from DART (http://www.cbr.washington.edu/dart/), accessed in January 2007.)

\subsubsection{River Discharge, Spill Operations, Forebay Elevation, and Temperature}

During the study (April 12 through July 16), daily outflow at TDA ranged from 151 to $391 \mathrm{kcfs}$ (Figure 4.2). Mean daily outflow was $325 \mathrm{kcfs}$ in spring (April 12 to June 4) and $254 \mathrm{kcfs}$ in summer (June 5 to July 16). Outflow peaked in late May (Figure 4.2). Total project outflow was greater than the ten-year average for both the spring and summer study periods (121\% in spring and $103 \%$ in summer). Daily turbine discharge averaged $197 \mathrm{kcfs}$ in spring and $145 \mathrm{kcfs}$ in summer. Daily spill flow during our study ranged from 61 to $217 \mathrm{kcfs}$, with a mean of $123 \mathrm{kcfs}$ ( $38 \%$ of total project) in spring and $104 \mathrm{kcfs}$ ( $41 \%$ of total project) in summer. Daily sluice flow was about $4.5 \mathrm{kcfs}$, depending on forebay elevation.

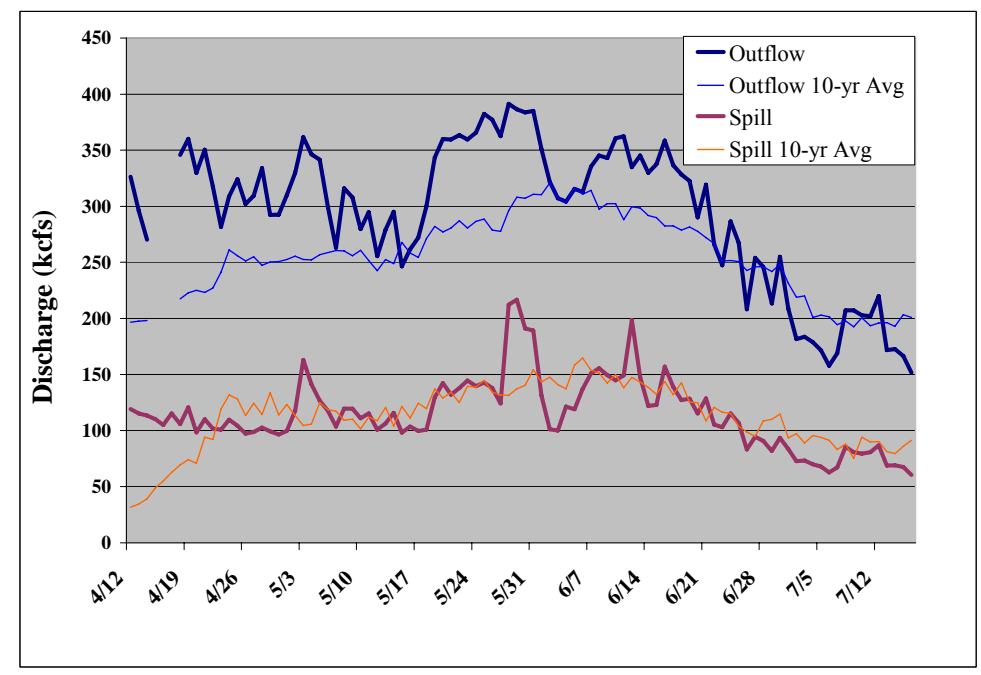

Figure 4.2. Daily Total Outflow and Spill for the 2006 Study Period and the 10-yr Average. (Data were obtained from DART (http://www.cbr.washington.edu/dart/), accessed January 2007.) 
Spill discharge was bulked in Bays 1-6 during both spring and summer 2006 (Figure 4.3). Spill above $\sim 120 \mathrm{kcfs}$ was discharged through Bays 7, 8, 9, and 14. (Bays 10-13 were off-line due to wire rope disrepair.)

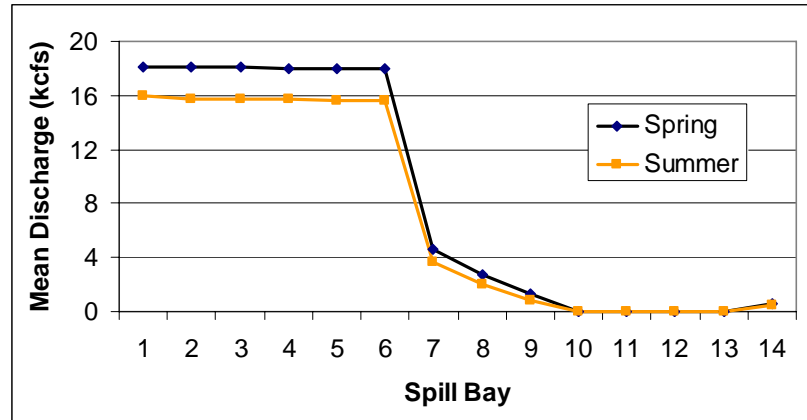

Figure 4.3. Mean Discharge by Spill Bay during Spring and Summer 2006 at The Dalles Dam. (Graph made from data provided by the USACE.)

Mean daily forebay elevation during the study ranged from $155.5 \mathrm{ft}$ to $159.1 \mathrm{ft}$ (Figure 4.4). Mean forebay elevation was $157.6 \mathrm{ft}$ in spring and $157.9 \mathrm{ft}$ in summer.

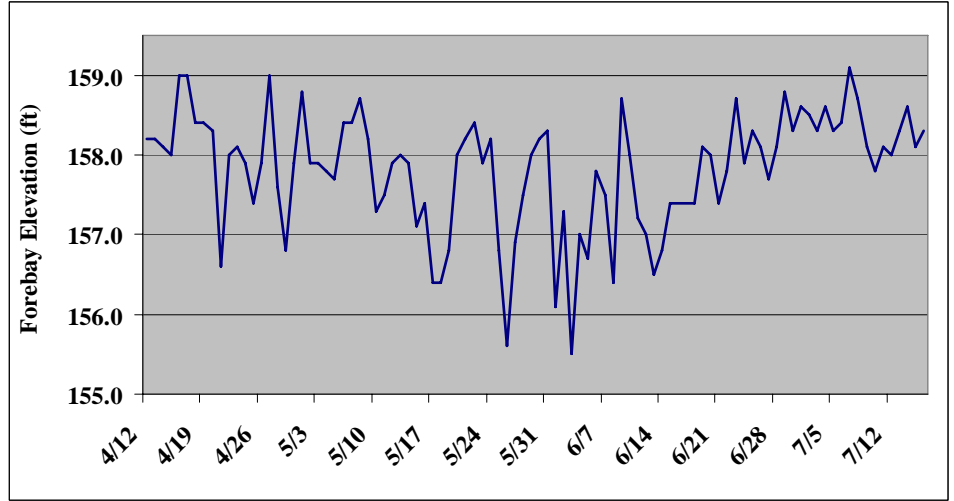

Figure 4.4. Mean Daily Forebay Elevation at The Dalles Dam during the 2006 Study Period. (Data were obtained from DART (http://www.cbr.washington.edu/dart/) in January 2007.)

Water temperature generally increased as the study progressed (Figure 4.5). It ranged from $8.5^{\circ} \mathrm{C}$ to $20.8^{\circ} \mathrm{C}$ and was similar to the 10 -year average in spring and $0.6^{\circ} \mathrm{C}$ warmer in summer.

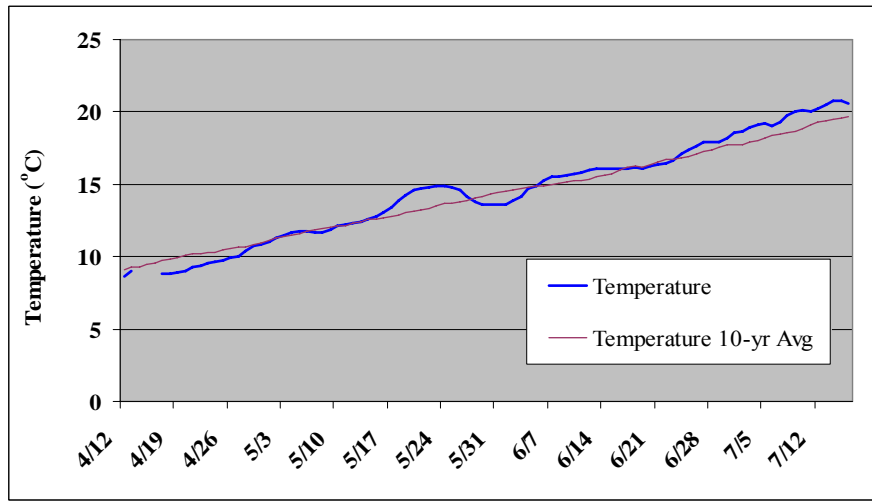

Figure 4.5. Mean Daily Temperature at The Dalles Dam during the 2006 Study Period. (Data were obtained from DART (http://www.cbr.washington.edu/dart/) in January 2007.) 


\subsubsection{Hydraulic Conditions}

We characterized hydraulic conditions at Spill Bays 1-6 using a CFD model. Water velocity patterns were similar for the six discharge cases we modeled, which varied by spillway and powerhouse discharge level (Table 3.2). Therefore, we offer Case 1 (Table 3.2) as a representative example. For a flow of 19.7 kcfs per bay, water velocity data are shown for two elevations (130 ft and $150 \mathrm{ft}$ ), which are $28 \mathrm{ft}$ and $8 \mathrm{ft}$ below the surface, respectively. Water velocity increased as flow approached the spillway (Figures 4.6 and 4.7). At elevation $130 \mathrm{ft}$, the CFD modeling shows very high velocities as water approached and entered into the bays (Figure 4.7). However, at elevation $150 \mathrm{ft}$, the modeling shows a more gradual increase in velocity as water approached a bay (Figure 4.7).

The formation of vortices is evident from angular velocities in front of each bay, then a reduction of speed once the water is in a bay (see Figures 4.7 and 4.9). Similar trends can be seen in the CFD modeling for a flow of $13.9 \mathrm{kcfs}$ per bay (Figures 4.8 and 4.9). More CFD data are presented in Section 4.3 on fish trajectories.

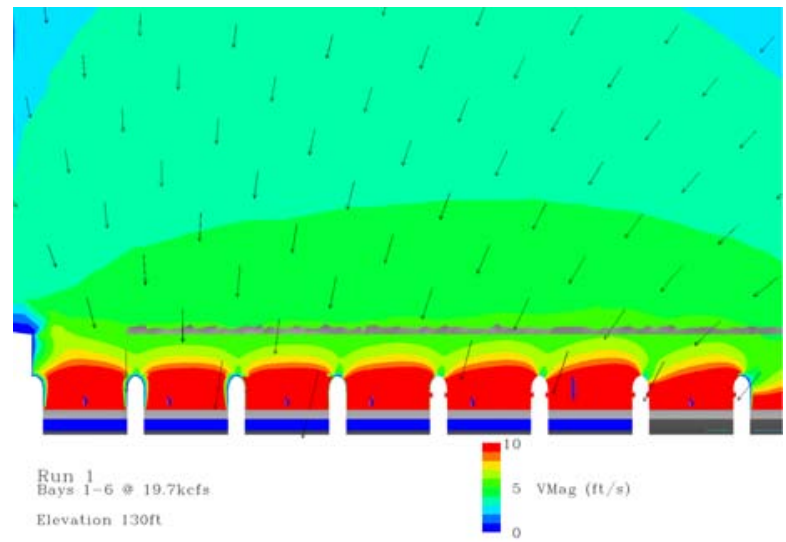

Figure 4.6. Plan View of Spillway Forebay Water Velocities from Elevation $130 \mathrm{ft}$ for Case 1 (Table 3.2).

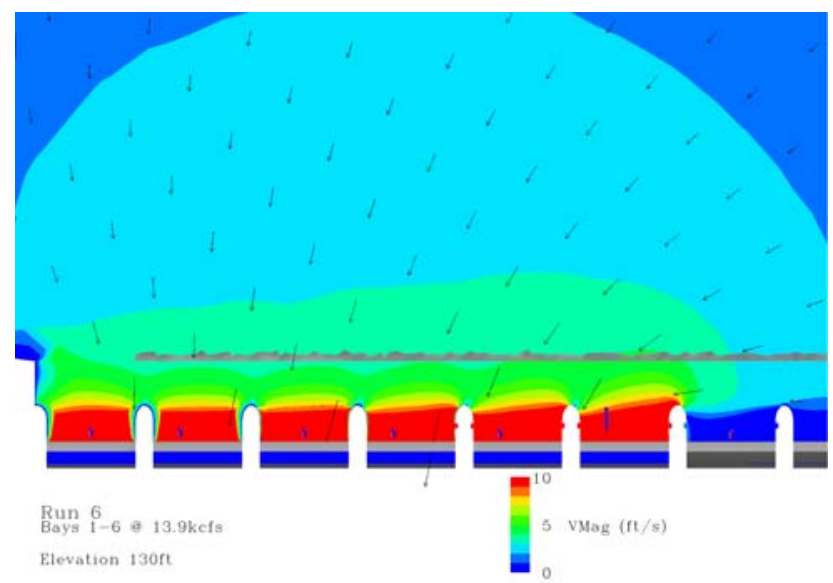

Figure 4.8. Plan View of Spillway Forebay Water Velocities at Bays $1-6$, from Elevation $130 \mathrm{ft}$ for Case 6 (Table 3.2).

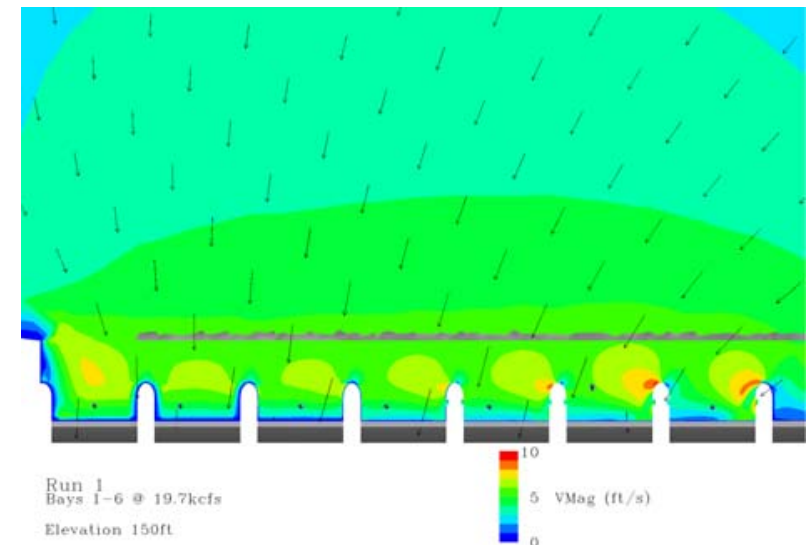

Figure 4.7. Plan View of Spillway Forebay Water Velocities from Elevation $150 \mathrm{ft}$ for Case 1 (Table 3.2).

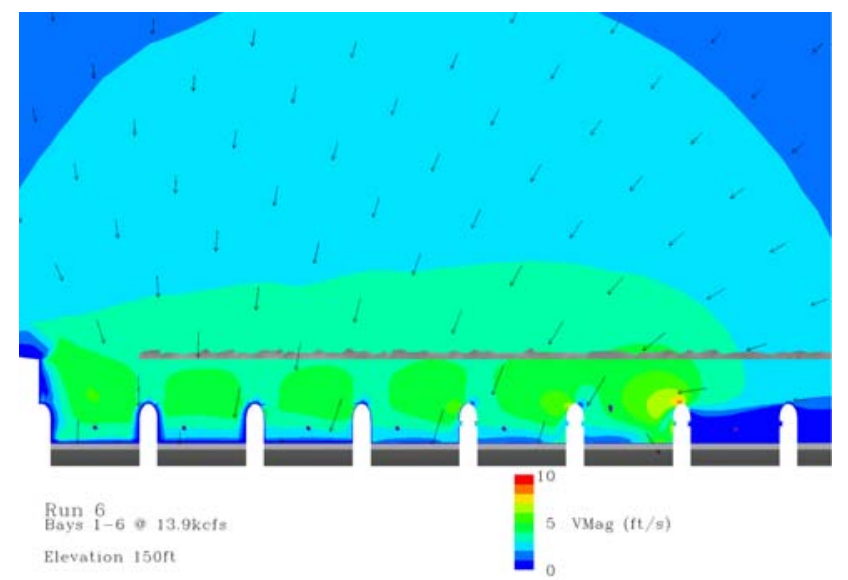

Figure 4.9. Plan View of Spillway Forebay Water Velocities at Bays $1-6$, from Elevation $150 \mathrm{ft}$ for Case 6 (Table 3.2). 


\subsection{Fish Passage Distributions}

The 2006 fish passage evaluation at The Dalles Dam spillway involved five types of fish distribution that were analyzed from the fixed location hydroacoustic data set collected immediately in front of the Tainter gates: daily, vertical, horizontal, intensive at Bays 5 and 6, and diel distributions.

\subsubsection{Daily Fish Passage}

A comparison of the peaks in the hydroacoustic and SMP passage indices showed a reasonable match (Figure 4.10). We did not lag the data to compensate for the fact that the hydroacoustic index is for The Dalles Dam and the SMP index is for John Day Dam because of the quick travel time $(<1 \mathrm{~d})$ from John Day to The Dalles Dam (e.g., Hansel et al. 2000). The spike in passage for May 10 as estimated from hydroacoustic data was likely due to the 568,054 yearling hatchery Chinook salmon released from the Warm Springs Hatchery on the Deschutes River downstream of John Day Dam between March 30 and April 26, 2006 (hatchery data are from http://www.fpc.org/hacthery/).

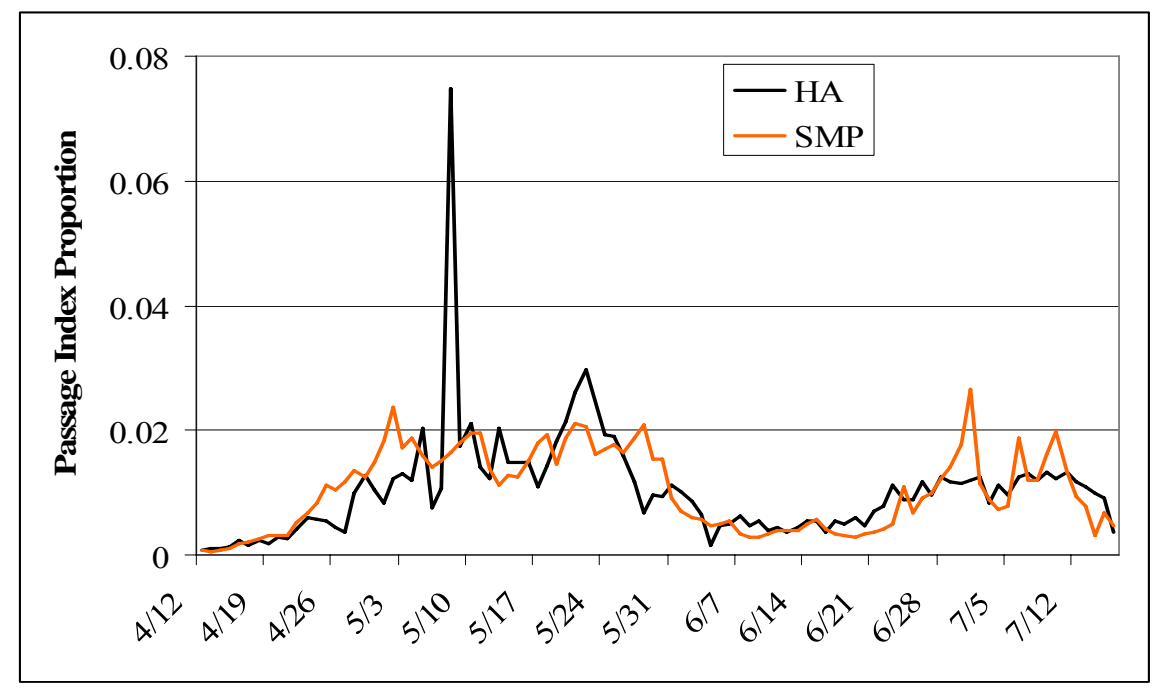

Figure 4.10. Fish Passage Indices for The Dalles Dam, 2006. Data are expressed as the daily proportion of the total for the April 12 to July 16 study period. The hydroacoustic index (HA) is for the run at large as sampled at TDA. The Smolt Monitoring Program index (SMP) is for all species combined as sampled at John Day Dam.

\subsubsection{Vertical Distribution}

The vertical distribution of fish passing through Spill Bays 1-9 and 14 at The Dalles Dam in 2006, analyzed by two-week time period (Figure 4.11), was skewed to the upper portion of the water column during the spring and the lower portion of the water column in the summer. The summer vertical distribution was dominated by passage during the period July 1-6 when subyearling Chinook salmon passage peaked at the dam (Figure 4.10). During spring, 20\% of the total fish used the top $5 \mathrm{~m}$ of the water column, but during summer $25 \%$ were passing at approximately $10-11 \mathrm{~m}$ deep. Further vertical distribution analyses by bay over the entire study and two-week time periods follow. 


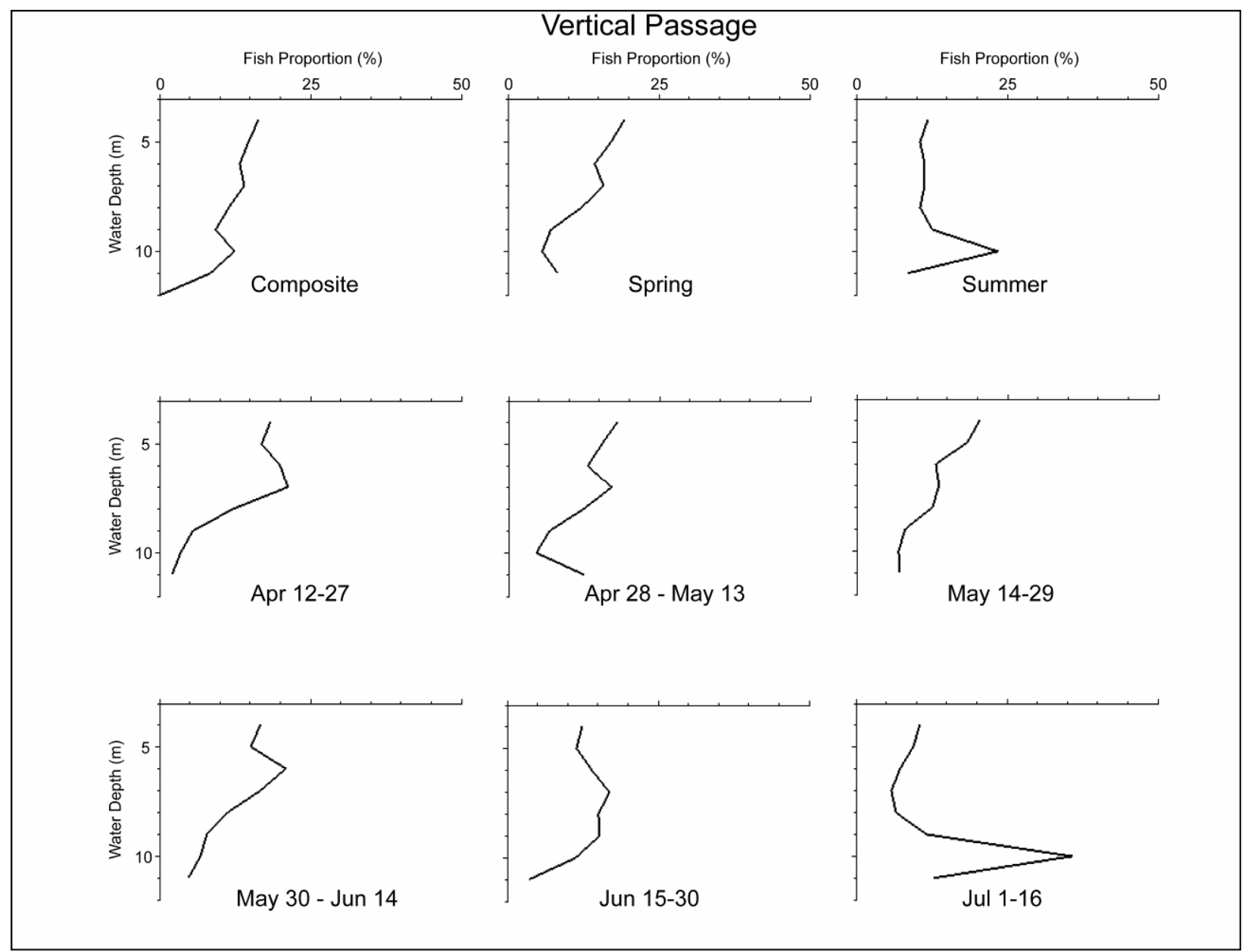

Figure 4.11. Vertical Distributions by Time Period at all Sampled Bays Combined at The Dalles Dam Spillway, 2006. Data are proportions of total passage for a given time period in 1-m-range bins from the 3-m depth to the ogee at 12-m depth. As an example, data for the 5-m water depth are for the 5-6 $\mathrm{m}$ depth bin. 
Vertical distributions by bay for the entire study period combined show patterns among spill bays (Figure 4.12). Bays 1-5 had similar distributions with the highest passage proportions typically toward the shallower range bins and a prominent peak at the 10-11 m depth bin. The vertical distribution at Bay 6, however, had peaks at 3-4 m and 10-11 m. Data from Bays 7-9 revealed vertical distributions skewed toward the surface.

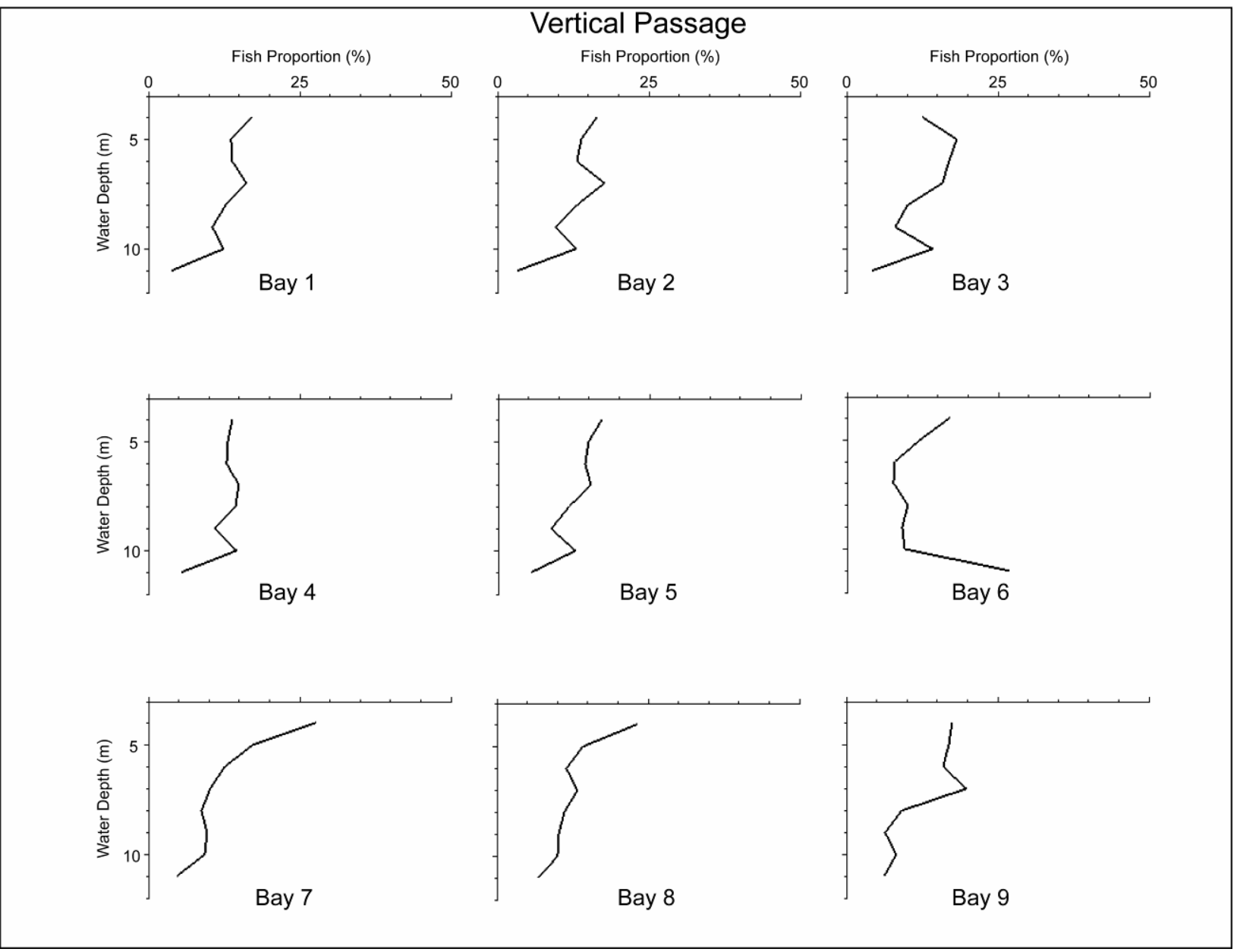

Figure 4.12. Vertical Distributions by Bay for the Entire Study Period Combined at The Dalles Dam Spillway, 2006. Data are proportions of total passage for a given bay in 1-m-range bins from the $3-\mathrm{m}$ depth to the ogee at $12-\mathrm{m}$ depth. 
Vertical distributions by bay by two-week time period show the temporal and spatial variability in vertical distributions at The Dalles Dam spillway in 2006 (Figure 4.13). These plots reveal the data behind the plots in Figures 4.11 and 4.12. For a given time period, vertical distributions among individual bays are similar, except for Bay 6 during April 28-May 13, May 14-May 29, and June 1-16. For a given bay, distributions across time periods were somewhat alike, except for the July 1-16 period when subyearling Chinook salmon predominated and passage peaked at most bays at a 10-11 m depth.

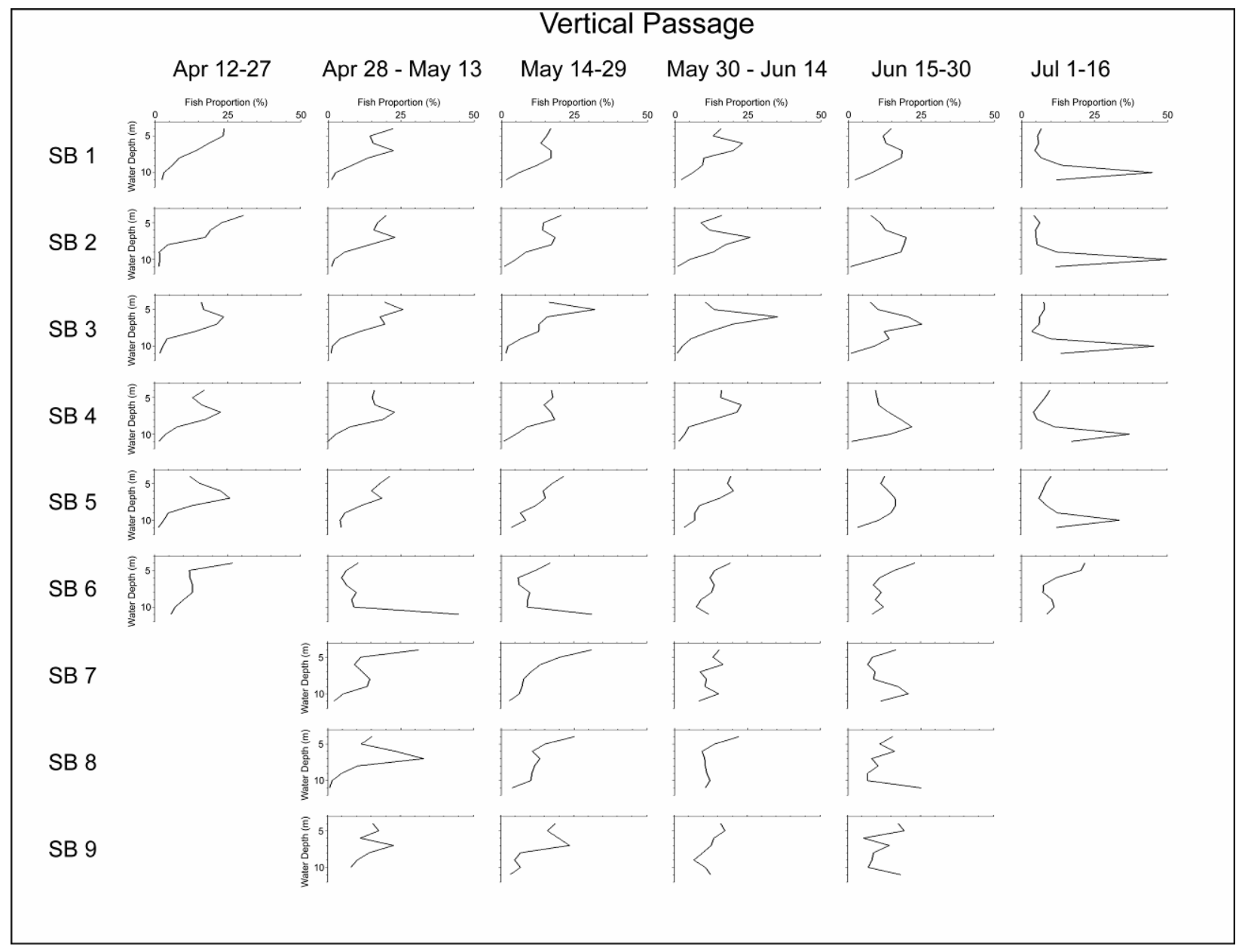

Figure 4.13. Vertical Distributions by Bay by Two-Week Time Period at The Dalles Dam Spillway, 2006. "SB" stands for spill bay. Data are proportions of total passage for a given bay in 1-mrange bins from the $3-\mathrm{m}$ depth to the ogee at $12-\mathrm{m}$ depth. 


\subsubsection{Horizontal Distribution: Passage and Density}

Juvenile salmonid passage at The Dalles Dam spillway peaked at Bay 6 during the 2006 study (Figure 4.14). This pattern was true across the spring and summer seasons and the two-week time periods. Passage rates gradually increased from Bay 1 to Bay 4, with a major increase at Bay 5, and a peak at Bay 6. Passage rates at Bays 7, 8, 9, and 14 were considerably lower than those at Bays 1-6 because Bays 7 and above were not operated nearly as frequently as the continuous operation at Bays 1-6.

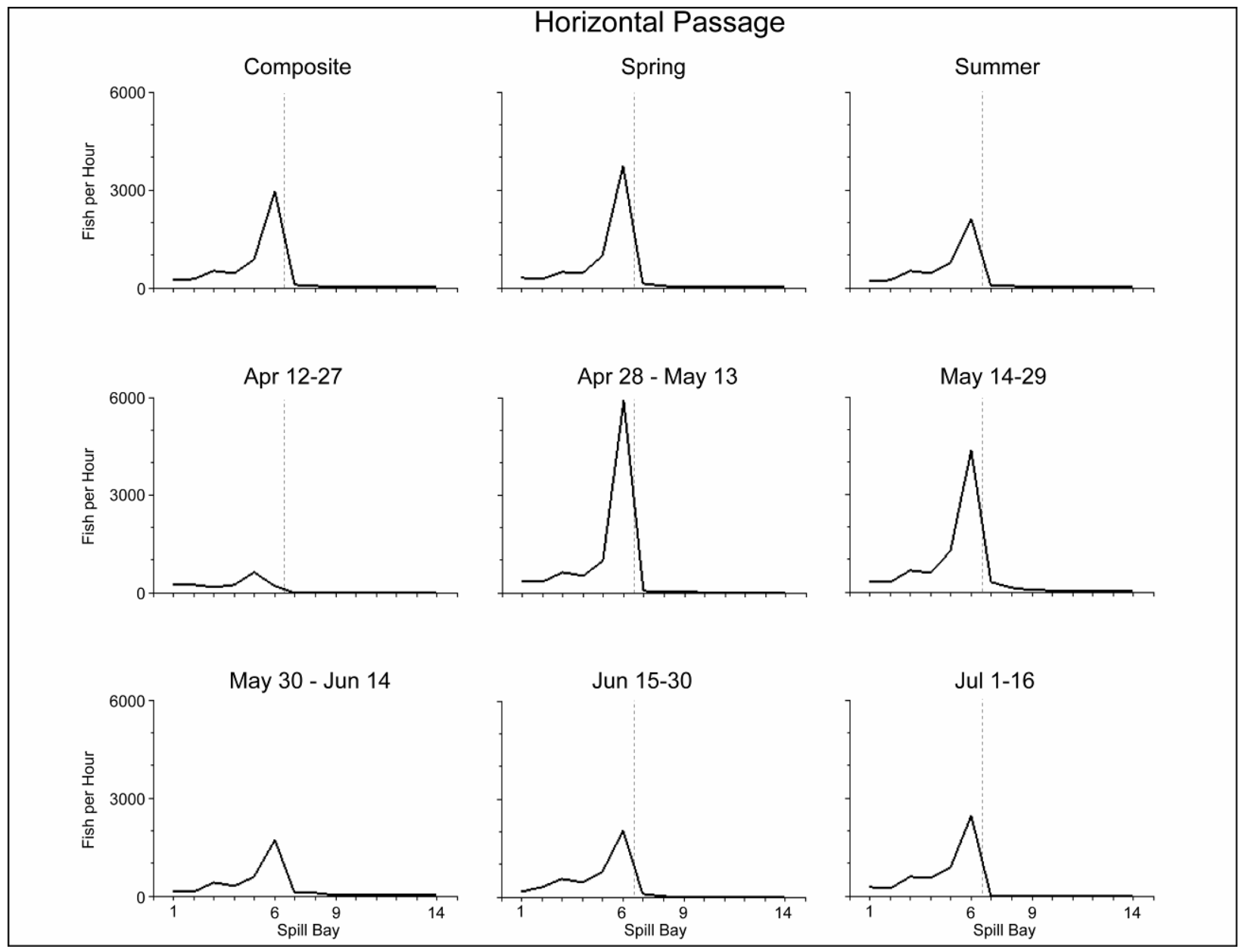

Figure 4.14. Horizontal Distributions of Fish Passage Rates (number per hour) by Time Period at The Dalles Dam Spillway, 2006. Data are average hourly rates by bay for a given time period. The vertical lines represent the spillwall in the stilling basin between Bays 6 and 7 . 
After normalizing for the amount of discharge by bay (Figure 4.15), the horizontal distribution was similar to that for the un-normalized data (Figure 4.14). At the spillway, the horizontal distribution of fish density, expressed as number of fish per hour per unit flow (kcfs), was highest at Bay 6 during both spring and summer (Figure 4.15). Bays 7-9 and 14 passed fish when they were open.

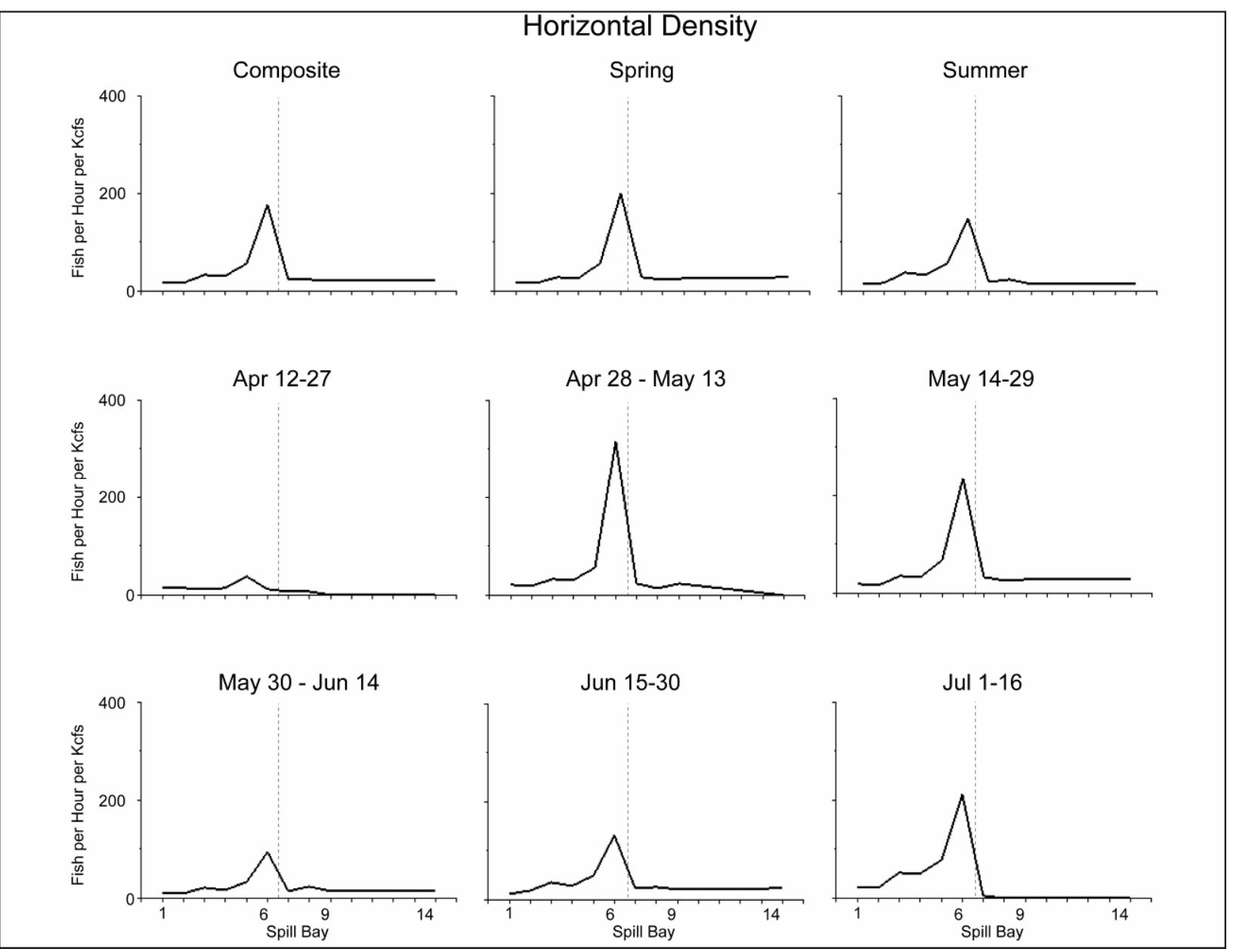

Figure 4.15. Horizontal Distributions of Fish Density (number of fish per hour per kcfs) by Time Period at The Dalles Dam Spillway, 2006. Data are average hourly rates normalized by average discharge $(\mathrm{kcfs})$ by bay for a given time period. The vertical line represents the spillwall in the stilling basin between Bays 6 and 7 . 


\subsubsection{Intensive Distribution at Bays 5 and 6}

The intensive vertical and horizontal distribution of fish passage at Bays 5 and 6 was much more variable during spring than summer and more variable at Bay 5 than Bay 6 for both study periods (Figure 4.16). For Bay 5, most fish appear to use the upper portion of the water column and the center of the bay in the spring months and the lower portion of the water column in the summer. Passage in Bay 6 was intensified in the lower portion of the water column and center of the bay in the spring, whereas in the summer months, fish appeared to use the uppermost portion of the water column.

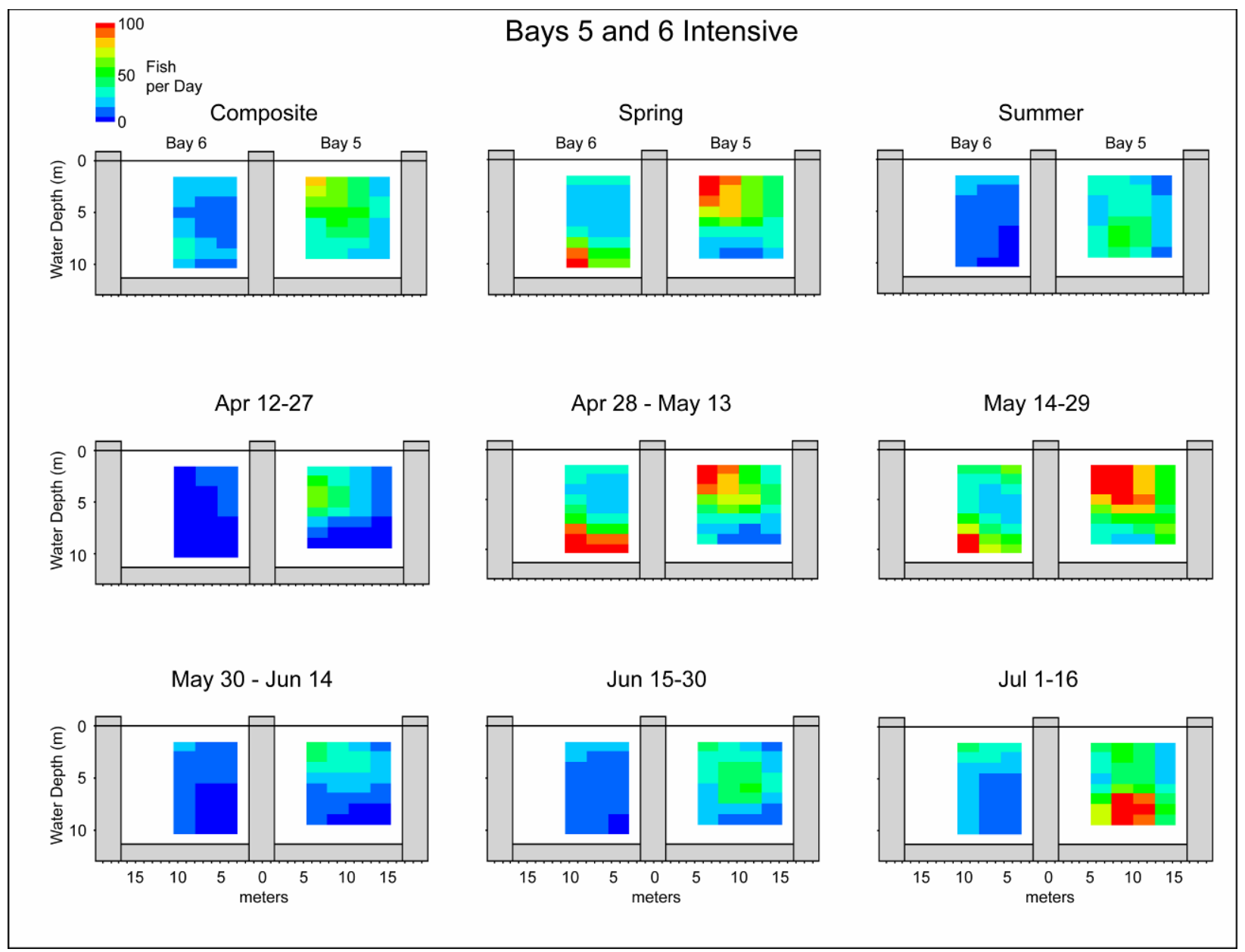

Figure 4.16. Intensive Distributions Vertically and Horizontally at Bays 5 and 6 by Time Period at The Dalles Dam Spillway, 2006. Data are mean daily passage rates by 1-m depth bin and horizontal location (one-fifth of a bay) for a given time period. The perspective is from the forebay looking downstream at the face of the spillway. 


\subsubsection{Diel Distribution}

The diel distribution of fish passage at the spillway peaked at dawn during spring and had minor crepuscular peaks during summer (Figure 4.17). During 2006, passage rates at the spillway were somewhat higher during day than night hours. The passage peak at dawn during the April 28-May 13 time period dominated the diel distribution data.

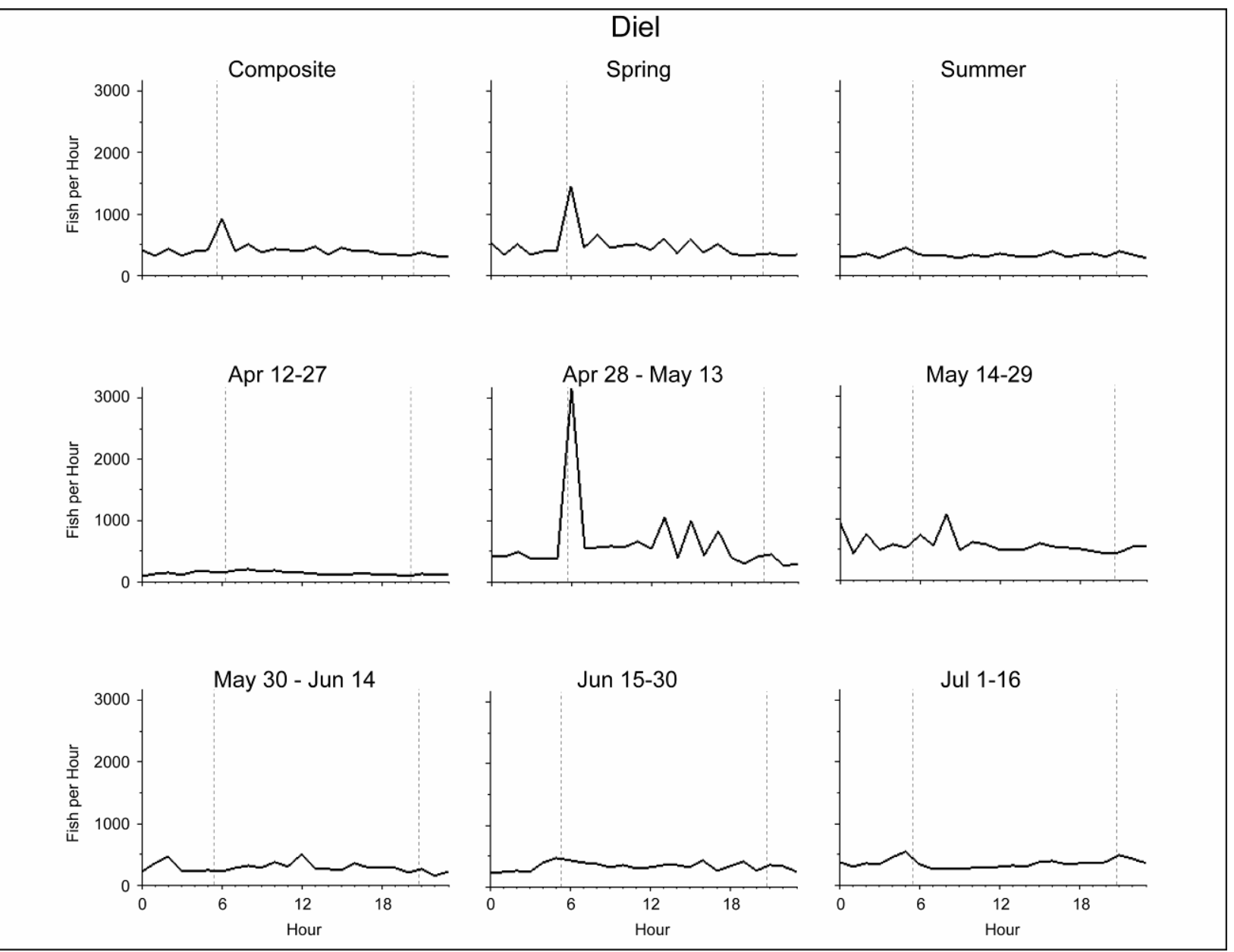

Figure 4.17. Diel Distribution for All Bays Combined at the Spillway by Time Period at The Dalles Dam Spillway, 2006. Data are mean hourly total spillway passage rates for a given time period. The vertical lines approximate the times of dawn and dusk. 


\subsection{Fish Trajectories Relative to Water Velocity}

Fish trajectories obtained from the split-beam hydroacoustic data closely matched the water velocity vectors from the CFD model (Figure 4.18). Fish velocity was slower than water velocity in depth bins immediately above the ogee, indicating fish were oriented upstream and swimming against the flow. Trajectories and water velocities were similar among bays.

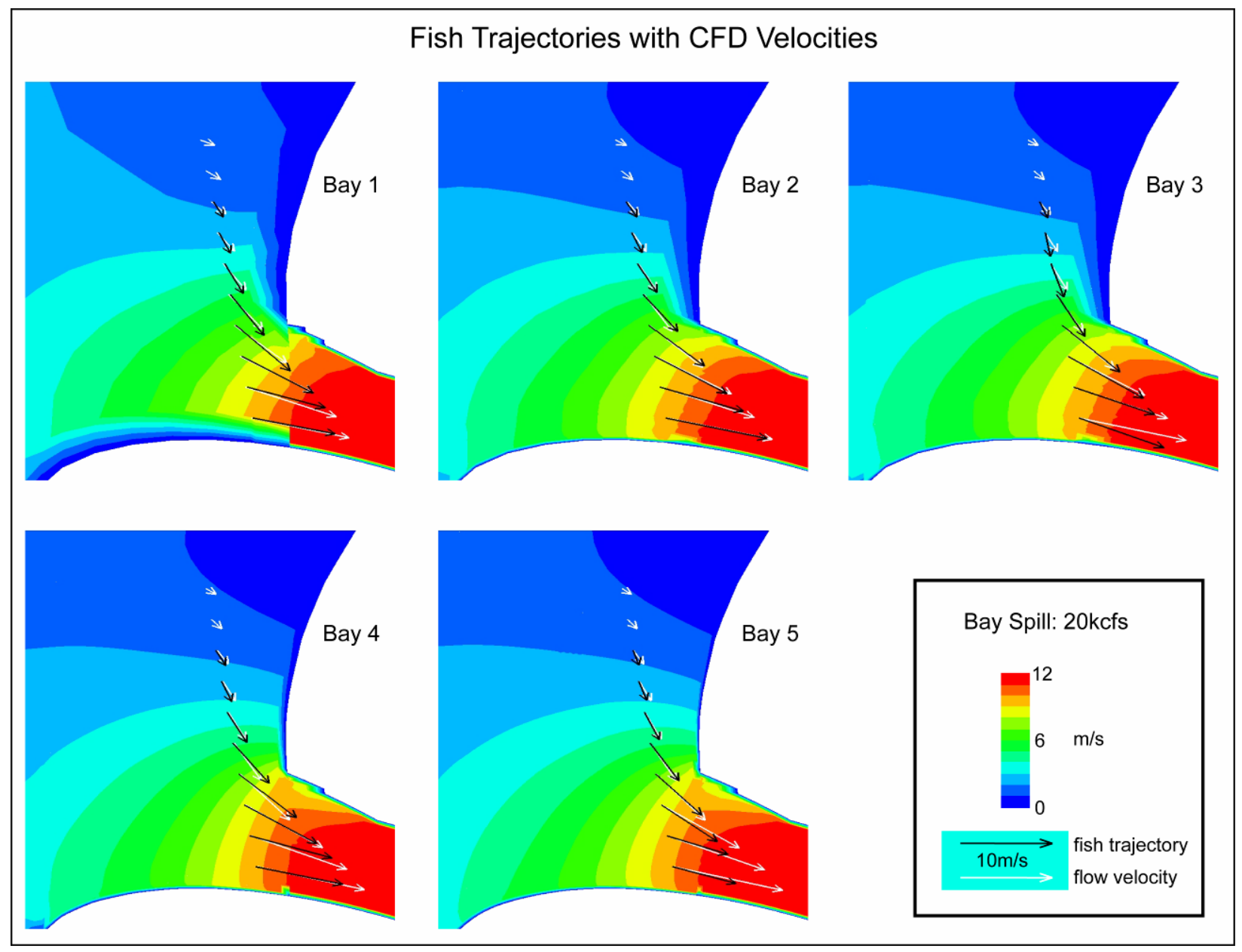

Figure 4.18. Fish Trajectories and Water Velocity Vectors by Bay for the Entire Study Period Combined at The Dalles Dam Spillway, 2006. Bay 6 is not shown because the fish trajectory and water velocity data were not obtained along the same locations. 
Hydroacoustic Evaluation of Juvenile Salmonid Passage at The Dalles Dam Spillway, 2006 


\subsection{Discussion and Conclusions}

The hydroacoustic evaluation of fish passage at The Dalles Dam spillway during 2006 addressed vertical, horizontal, intensive, and diel fish distributions and fish trajectories. These data are intended to help document the baseline condition before installation of a vortex suppression device and, in general, provide fundamental data on juvenile salmonid passage at the spillway.

A relatively high concentration of fish was present in the top $15 \mathrm{ft}$ of the water column during April and May, but during June and July the concentration of fish was deeper in the water column, approximately $30 \mathrm{ft}$ below the surface. The deeper vertical distribution for summer subyearling migrants than for spring yearling migrants substantiates previous findings at The Dalles Dam (Johnson et al. 2003, 2005, 2007). Note that the hydroacoustic sampling location just upstream of the Tainter gates at the spillway means the vertical distribution data are influenced downward by bottom spill at the ogee $37 \mathrm{ft}$ deep, i.e., vertical distributions in the forebay proper would be higher in the water column than those presented here.

The horizontal distribution of fish passage increased from Bay 1 to 5 and peaked at Bay 6 . This was true for both passage rates $(\# / \mathrm{h})$ and densities $(\# / \mathrm{h} / \mathrm{kcfs})$, which was expected because spill discharge was reasonably uniform across Bays 1-6. When Bays 7-9 had to be opened because of high flow conditions (greater than $300 \mathrm{kcfs}$ total project discharge), juvenile salmonids passed at these locations. The skew in horizontal distribution toward Bays 5 and 6 during bulk spill is consistent with previous horizontal distribution studies for this spillway operation (Johnson et al. 2005; Hansel et al. 2005). While we did not directly observe fish becoming entrained in the vortex at Bay 6 , our side-looking transducer beam upstream of the vortex did detect more fish moving toward the vortex in the southern corner of Bay 6 than toward the center of the bay where there was no vortex. A primary approach path to the spillway is from the powerhouse across the spillway forebay obliquely to the first available open southern bays (Beeman et al. 2005, 2006; Cash et al. 2005). This approach path means fish are vulnerable to entrainment in the Bay 5 and 6 vortices, as is indicated in the horizontal distribution of fish passage.

The intensive distribution at Bays 5 and 6 combined vertical and horizontal distribution data to increase the resolution of passage distribution within a given bay. We observed that, although fish passage is patchy spatially and temporally, there were some patterns. For example, during April 28-May 29, passage was highest in Bay 5 in the upper center of the bay while passage at Bay 6 was highest in the lower center. An implication from these data is that multiple locations 15-30 ft deep for release pipes for tagged fish as part of injury and survival studies may be needed for the results to be approximately representative of run-of-river fish.

The diel distribution during the 2006 study showed that passage at the spillway was highest in the early to mid-morning hours. Hourly passage distribution data were more variable in the spring than summer. Over all study years, diel passage at the spillway shows no consistent pattern (Johnson et al. 2007) - fish seem to pass the spillway shortly after they encounter it no matter the time of day. The diel passage data indicate spill operations $24 \mathrm{~h} / \mathrm{d}$ are beneficial to fish passage by providing a non-turbine passage route around the clock.

Fish trajectories matched water velocity vectors. Fish tracked in the hydroacoustic sample volumes followed the flow lines upstream of the ogee. This pattern was consistent across bays and indicated fish were entrained in spill discharge, especially directly upstream of the ogee. Given the spill discharges greater than $15 \mathrm{kcfs}$ per bay, this is expected. Measured fish velocities were slightly slower than modeled 
water velocities. It is reasonable to assume the modeled discharges were representative of field conditions under which fish trajectories were sampled; thus, the data indicate fish on average were swimming against the flow with a positively rheotactic orientation.

In conclusion, this investigation for the Spillway Improvements Study used fixed-location hydroacoustics and CFD modeling to determine detailed daily, vertical, horizontal, intensive, and diel distributions of juvenile salmonid passage and trajectories relative to water velocity at the spillway at The Dalles Dam from April 12 to July 16, 2006. Spill at approximately 16 to $18 \mathrm{kcfs}$ per bay was bulked at Bays 1-6, although other bays were opened at times during the study to maintain a $40 \%$ spill percentage out of total project discharge. We arrived at the following conclusions.

- Daily passage corresponded with the smolt monitoring index data from John Day, except for a passage peak at The Dalles Dam on May 10 likely due to hatchery releases in the Deschutes watershed.

- Vertical distribution of fish was skewed toward the surface during spring, but during summer passage peaked at 1-2 $\mathrm{m}$ above the spillway ogee.

- Horizontal distribution in terms of fish passage rates (number per hour) and fish densities (number per kcfs) was highest at Bay 6, followed by passage at Bay 5 .

- Intensive vertical and horizontal distribution of fish passage at Bays 5 and 6 was much more variable during spring than summer and more variable at Bay 5 than Bay 6 .

- Diel distribution data revealed that fish passage was highest during 0600-0700 h in spring; otherwise passage was reasonably uniform on a diel basis.

- Fish trajectories matched water velocity vectors. 


\subsection{Literature Cited}

Beeman, J. W., H. C. Hansel, P. V. Haner, and K. Daniel. 2005. Estimates of Fish, Spill, and Sluiceway Passage Efficiencies of Radio-Tagged Juvenile Steelhead and Yearling Chinook Salmon at The Dalles Dam, 2001. Final report of research submitted to the U.S. Army Corps of Engineers Portland District by the USGS Biological Resources Division, Cook, WA.

Beeman, J. W., S. D. Juhnke, H. C. Hansel, A. J. Daniel, L. L. Dingmon, P. V. Haner, and T. L. Liedtke. 2006. Estimates of the Stilling Basin Residence Time and Lateral Distribution of Juvenile Chinook Salmon Passing through the Spillway at The Dalles Dam during 2002. Final report of research submitted to the U.S. Army Corps of Engineers - Portland District by the USGS Biological Resources Division, Cook, WA.

Carlson, T. J., W. C. Acker, and D. M. Gaudet. 1981. Hydroacoustic Assessment of Downstream Migrant Salmon and Steelhead at Priest Rapids Dam in 1980. APL-UW 8016. Applied Physics Laboratory, University of Washington, Seattle, WA.

Cash, K. and 13 co-authors. 2005. Three-Dimensional Behavior and Passage of Juvenile Salmonids at The Dalles Dam, 2004. Draft final report of research submitted to the U.S. Army Corps of Engineers - Portland District by the USGS Biological Resources Division, Cook, WA.

Deng, Z., C. B., M. C. Richmond, and T. J. Carlson. 2006. Characterization of The Dalles Dam Spillbay 6 Vortex Using Surface Entrained Sensor Fish Device. PNNL-15883. Final report submitted to the U.S. Army Corps of Engineers -- Portland District by the Pacific Northwest National Laboratory, Richland, WA.

Faber, D. M,. M. E. Hanks, S. A. Zimmerman, J. R. Skalski, and P. W. Dillingham. 2005. The Distribution and Flux of Fish in the Forebay of The Dalles Dam in 2003. PNNL-14628. Final report submitted to the U.S. Army Corps of Engineers -- Portland District by the Pacific Northwest National Laboratory, Richland, WA.

Hansel, H. C., and six co-authors. 2000. Estimates of Fish-, Spill-, and Sluiceway Passage Efficiencies of Radio-Tagged Juvenile Steelhead and Yearling Chinook Salmon at The Dalles Dam, 1999. Annual report of research submitted to the U.S. Army Corps of Engineers - Portland District by the USGS Biological Resources Division, Cook, WA.

Hansel, H. C., J. W. Beeman, S. D. Juhnke, P. V. Haner, and L. L. Dingmon. 2005. Estimates of Fish-, Spill-, and Sluiceway Efficiencies of Radio-Tagged Juvenile Chinook Salmon during Spring and Summer at The Dalles Dam in 2004. Annual report of research submitted to the U.S. Army Corps of Engineers - Portland District by the USGS Biological Resources Division, Cook, WA.

Hansel, H. C., S. D. Juhnke, P. V. Haner, L. L. Dingmon, and J. W. Beeman. 2007. Estimates of Fish-, Spill-, and Sluiceway-Passage Efficiencies of Radio-Tagged Juvenile Chinook Salmon during Spring and Summer at The Dalles Dam in 2005. Draft final report of research submitted to the U.S. Army Corps of Engineers - Portland District by the USGS Biological Resources Division, Cook, WA. 
Hausmann, B., J. Beeman, H. Hansel, S. Juhnke, and P. Haner. 2004. Estimates of Fish, Spill, and Sluiceway Passage Efficiencies of Radio-Tagged Juvenile Salmonids Relative to the Sluiceway Guidance Improvement Device at The Dalles Dam in 2002. Final report of research submitted to the U.S. Army Corps of Engineers - Portland District by the USGS Biological Resources Division, Cook, WA.

Johnson, G. E. 2000. Assessment of the Acoustic Screen Model to Estimate Smolt Passage Rates at Dams: Case Study at The Dalles Dam in 1999. Final report by BioAnalysts, Inc. submitted to the USACE Waterways Experiment Station, Vicksburg, MS.

Johnson, G. E., R. A. Moursund, and R. P. Mueller. 2003. Hydroacoustic Evaluation of the J-Occlusion Plates at the Dalles Dam in 2002. PNWD-3226. Final report submitted to the U.S. Army Corps of Engineers -- Portland District by Battelle, Pacific Northwest Division, Richland, WA.

Johnson, G. E., M. E. Hanks, F. Khan, J. B. Hedgepeth, R. P. Mueller, C. L. Rakowski, M. C. Richmond, S. L. Sargeant, J. A. Serkowski, and J. R. Skalski. 2005. Hydroacoustic Evaluation of Juvenile Salmonid Passage at The Dalles Dam in 2004. PNNL-15180. Final report submitted to the U.S. Army Corps of Engineers -- Portland District by the Pacific Northwest National Laboratory, Richland, WA.

Johnson, G. E., F. Khan, J. B. Hedgepeth, R. P. Mueller, C. L. Rakowski, M. C. Richmond, J. A. Serkowski, and J. R. Skalski. 2006. Hydroacoustic Evaluation of Juvenile Salmonid at The Dalles Dam Sluiceway, 2005. PNNL-15540. Final report submitted to the U.S. Army Corps of Engineers -- Portland District by the Pacific Northwest National Laboratory, Richland, WA.

Johnson, G. E., J. W. Beeman, I. N. Duran, and A. L. Puls. 2007. Synthesis of Juvenile Salmonid Passage Studies at The Dalles Dam, Volume II, 2001-2005. PNNL-16443. Draft report submitted to the U.S. Army Corps of Engineers, Portland District by the Pacific Northwest National Laboratory, Richland, WA and the USGS Biological Resources Division, Cook, WA.

MacLennan, D. N. and E. J. Simmonds. 1992. Fisheries Acoustics. Chapman and Hall, London.

Moursund, R. A., K. D. Ham, P. S. Titzler, R. P. Mueller, G. E. Johnson, J. Hedgepeth, and J. R. Skalski. 2002. Hydroacoustic Evaluation of Fish Passage at The Dalles Dam in 2001. Final report submitted to the U.S. Army Corps of Engineers -- Portland District by the Pacific Northwest National Laboratory, Richland, WA.

Ploskey G., T. Poe, A. Giorgi, and G. Johnson. 2001. Synthesis of Radio Telemetry, Hydroacoustic, and Survival Studies of Juvenile Salmon at The Dalles Dam (1982-2000). PNWD-3131. Final report submitted to the U.S. Army Corps of Engineers -- Portland District by the Pacific Northwest National Laboratory, Richland, WA.

Thorne, R. and G. Johnson. 1993. "A Review of Hydroacoustic Studies for Estimation of Salmonid Downriver Migration Past Hydroelectric Facilities on the Columbia and Snake Rivers in the 1980s." Reviews in Fisheries Science 1:27-56.

Vischer, D. L. and W. H. Hager. Dam Hydraulics. John Wiley and Sons, West Sussex, England. 


\title{
Appendix A
}

\section{Statistical Synopsis for The Dalles Spillway Hydroacoustic Evaluations in 2006}

\author{
Prepared for: \\ Gary Johnson \\ Pacific Northwest National Laboratory \\ 620 SW Fifth Avenue, Suite 810 \\ Portland, Oregon 97204 \\ Prepared by: \\ John R. Skalski \\ Columbia Basin Research \\ School of Aquatic and Fishery Sciences \\ University of Washington \\ 1325 Fourth Avenue, Suite 1820 \\ Seattle, Washington 98101
}

June 8, 2006 
Hydroacoustic Evaluation of Juvenile Salmonid Passage at The Dalles Dam Spillway, 2006 


\section{Appendix A}

\section{Statistical Synopsis for The Dalles Spillway Hydroacoustic Evaluations in 2006}

The purpose of this statistical synopsis is to describe the statistical methods to be used in the analysis of the 2006 hydroacoustic study at The Dalles spillway. The study will estimate fish passage and vertical and horizontal distributions through the spillway under different spill conditions during the spring and summer seasons. The investigation is an observational study with no a priori or planned treatment comparisons.

\section{Transducer Deployment and Sampling Scheme}

Only the spillway is sampled at The Dalles Dam in 2006. Transducers were located in spill bays 1-9 and 14, as described in Table A.1. Within a spillbay, allocated transducers were randomly located among five horizontal positions (i.e., N, NC, C, SC, S) with the exception of spill bays 5 and 6 . Because of vortices in the corner of these spillbays, only the three most northern positions $(\mathrm{N}, \mathrm{NC}, \mathrm{C})$ of Bay 6 and the four most northern positions (N, NC, C, SC) of Bay 5 could be sampled.

Table A.1. Distribution of Hydroacoustic Transducers per Spillbay and Sampling Intensity per Transducer within an Hour

\begin{tabular}{ccl}
\hline Spillbay & No. of transducers & Sampling intensity per hr \\
\hline 1 & 1 & 15 1-min samples \\
2 & 1 & 15 1-min samples \\
3 & 2 & 15 1-min samples each \\
4 & 2 & 151 -min samples each \\
5 & 4 & 2 @ 15 1-min, 2 @ 20 1-min \\
6 & 3 & 201 -min samples each \\
7 & 1 & 201 -min samples \\
8 & 1 & 201 -min samples \\
9 & 1 & 201 -min samples \\
14 & 1 & 201 -min samples \\
\hline
\end{tabular}

The priority for the spillbays at The Dalles is 1-6, followed by 7, 8, 9, and, if needed, 14 . Spillbays 1 through 6 will be used throughout the study with additional bays as needed due to flow volumes. 


\section{Estimating Fish Passage}

The following section describes how the estimate of smolt passage will be calculated at the various spillbays.

\section{Spillbays with One Transducer (i.e., 1, 2, 7, 8, 9, 14)}

The sampling at a spillbay can be envisioned as a two-stage sampling scheme. The first stage is the random selection of 1 of $\mathrm{L}=5$ horizontal positions. The second stage is the characterization of smolt passage over time at those locations based on stratified random sampling. Passage through the single position will be expanded by a factor of five to estimate passage through the entire bay according to the formula

$$
\hat{S}=5 \sum_{i=1}^{D} \sum_{j=1}^{24}\left[\frac{A_{l}}{a_{l}}\left(\sum_{k=1}^{a_{l}} x_{i j k l}\right)\right],
$$

where

$X_{i j k l}=$ expanded fish count in the $k$ th sample $\left(k=1, \ldots, a_{k l}\right)$ in the $j$ th hour

$(j=1, \ldots, 24)$ of the $i$ th day $(i=1, \ldots, D)$ at the lth horizontal position of the spillbay;

$a_{l}=$ number of samples collected per hour at the $l$ th $(l=1)$ horizontal position within a spillbay (nominally, $a_{l}=15$ or 20 );

$A_{1}=$ total number of possible samples collected per hour at the $l$ th $(l=1)$ horizontal position within a spillbay (nominally, $A_{1}=60$ ).

The variance of $\hat{S}$ can be expressed as

$$
\operatorname{Var}(\hat{S})=25 \sum_{i=1}^{D} \sum_{j=1}^{24}\left[\frac{A_{l}^{2}\left(1-\frac{a_{l}}{A_{l}}\right) S_{x_{i j l}^{2}}}{a_{l}}\right]
$$

and estimated by

$$
\widehat{\operatorname{Var}}(\hat{S})=25 \sum_{i=1}^{D} \sum_{j=1}^{24}\left[\frac{A_{l}^{2}\left(1-\frac{a_{l}}{A_{l}}\right) s_{x_{i j l}}^{2}}{a_{l}}\right],
$$

where

$$
s_{x_{i j l}}^{2}=\frac{\sum_{k=1}^{a_{l}}\left(x_{i j k l}-\bar{x}_{i j l}\right)^{2}}{\left(a_{l}-1\right)}
$$

and where 


$$
\bar{X}_{i j l}=\frac{\sum_{k=1}^{a_{l}} X_{i j k l}}{a_{l}} \text {. }
$$

\section{Spillbays with Two or More Random Transducers (i.e., 3, 4)}

With two or more horizontal positions randomly selected, within-bay-position-to-position variability can be incorporated in the variance calculations. The estimate of total fish passage is estimated by

$$
\hat{S}=\sum_{i=1}^{D} \sum_{j=1}^{24} \frac{B}{b} \sum_{l=1}^{b}\left[\frac{A_{l}}{a_{l}} \sum_{k=1}^{a_{l}} x_{i j k l}\right],
$$

where

$$
\begin{aligned}
& b=\text { number of horizontal positions sampled within a spillbay; } \\
& B=\text { total number of horizontal positions within a spillbay (nominally, } B=5 \text { ). }
\end{aligned}
$$

The variance of (3) is estimated by

$$
\widehat{\operatorname{Var}}(\hat{S})=\sum_{i=1}^{D} \sum_{j=1}^{24}\left[\frac{B^{2}\left(1-\frac{b}{B}\right)}{b} s_{\hat{S}_{i j l}}^{2}\right]+\sum_{i=1}^{D} \sum_{j=1}^{24} \frac{B}{b}\left[\sum_{l=1}^{b} \frac{A_{l}^{2}\left(1-\frac{a_{l}}{A_{l}}\right) s_{x_{i j l}^{2}}^{2}}{a_{l}}\right],
$$

where

$$
s_{\hat{S}_{i j l}^{2}}^{2}=\frac{\sum_{l=1}^{b}\left(\hat{S}_{i j l}-\hat{\bar{S}}_{i j}\right)^{2}}{b-1}
$$

and where

$$
\begin{aligned}
& \hat{S}_{i j l}=\frac{A_{l}}{a_{l}} \sum_{k=1}^{a_{l}} x_{i j k l}, \\
& \hat{\bar{S}}_{i j}=\frac{\sum_{l=1}^{b} \hat{S}_{i j l}}{b} .
\end{aligned}
$$

\section{Spillbays with Restricted Sampling}

At Spillbays 5 and 6, horizontal sampling was limited by the presence of a corner vortex. All other available, non-vortex positions were sampled. In order to estimate total passage when part of the domain cannot be sampled, certain assumptions must be made. One option is to assume random sampling was used and estimate passage by Eq. (3) and its variance by Eq. (4). However, the presence of the vortex suggests areas sampled may not be representative of areas that could not be sampled. Hence, Eqs. (3)-(4) may have unspecified biases. 
Another option is to use a horizontal-aimed transducer to estimate the horizontal distribution across the face of the spillbays. This information, along with an estimate of absolute passage through part of the spillbay, could be used to provide a more accurate estimate of total passage.

\section{Estimate of Total Passage}

Let $\tilde{S}$ be an estimate of total passage through part of spillBay 5 or 6 that was actually sampled. Then total passage through the entire spillbay can be estimated as

$$
\hat{S}=\frac{\tilde{S}}{\tilde{p}},
$$

where $\tilde{p}=$ proportion of total passage through the spillbay that was through the area sampled to estimate $\tilde{S}$.

Because $\tilde{S}$ and $\tilde{p}$ are estimated independently, the variance of $\hat{S}$ can be estimated by the delta method approximation, where

$$
\widehat{\operatorname{Var}}(\hat{S})=\hat{S}^{2}\left[\frac{\widehat{\operatorname{Var}}(\tilde{S})}{\tilde{S}^{2}}+\frac{\widehat{\operatorname{Var}}(\tilde{p})}{\tilde{p}^{2}}\right] .
$$

\section{Spill Passage through the Restricted Zone}

For $\tilde{S}$, defined as

$$
\tilde{S}=\sum_{i=1}^{D} \sum_{j=1}^{24} \sum_{l=1}^{b}\left[\frac{A_{l}}{a_{l}} \sum_{k=1}^{a_{l}} x_{i j k l}\right],
$$

the variance can be estimated by

$$
\widehat{\operatorname{Var}}(\tilde{S})=\sum_{i=1}^{D} \sum_{j=1}^{24} \sum_{l=1}^{b}\left[\frac{A_{l}^{2}\left(1-\frac{a_{l}}{A_{l}}\right) s_{x_{i j l}^{2}}^{2}}{a_{l}}\right] .
$$

\section{Estimate of Horizontal Distribution}

Using a single horizontal beam, fish counts will be estimated within distance categories. Define the following:

$y_{i j k}=$ number of fish in the vertically sampled zone (see Section 3.3.2) of the spillbay for the $k$ th sample $(k=1, \ldots, a)$ in the $j$ th hour $(j=1, \ldots, 24)$ of the $i$ th day $(i=1, \ldots, D)$;

$Z_{i j k}=$ number of fish in the unsampled zone of the spillbay for the $k$ th sample $(k=1, \ldots, a)$ in the $j$ th hour $(j=1, \ldots, 24)$ of the $i$ th day $(i=1, \ldots, D)$.

Then $\tilde{p}$ can be estimated by

$$
\tilde{p}=\frac{y}{y_{.}+z},
$$

where 


$$
\begin{aligned}
& y_{.}=\sum_{i=1}^{D} \sum_{j=1}^{24} \sum_{k=1}^{a} y_{i j k}, \\
& z_{.}=\sum_{i=1}^{D} \sum_{j=1}^{24} \sum_{k=1}^{a} z_{i j k} .
\end{aligned}
$$

The variance of $\tilde{p}$ can be estimated by

$$
\widehat{\operatorname{Var}}(\tilde{p})=\tilde{p}^{2}\left(1-\tilde{p}^{2}\right)\left[\frac{\widehat{\operatorname{Var}}\left(y_{.}\right)}{y_{.}^{2}}+\frac{\widehat{\operatorname{Var}}\left(z_{\bullet}\right)}{z_{.}^{2}}-\frac{2 \operatorname{Cov}\left(y_{.}, z_{.}\right)}{y_{.} z_{.}}\right],
$$

where

$$
\widehat{\operatorname{Var}}\left(y_{.}\right)=\sum_{i=1}^{D} \sum_{j=1}^{24} a\left(1-\frac{a}{A}\right) s_{y_{i j}}^{2}
$$

and where

$$
\begin{aligned}
& s_{y_{i j}^{2}}=\frac{\sum_{k=1}^{a}\left(y_{i j k}-\bar{y}_{i j}\right)^{2}}{(a-1)}, \\
& \bar{y}_{i j}=\frac{\sum_{k=1}^{a} y_{i j k}}{a},
\end{aligned}
$$

and $\widehat{\operatorname{Var}}(\hat{z}$. $)$ calculated analogously. The covariance between $y$. and $z$. is estimated by

$$
\widehat{\operatorname{Cov}}\left(y_{.}, z_{.}\right)=\sum_{i=1}^{D} \sum_{j=1}^{24}\left[a\left(1-\frac{a}{A}\right) \operatorname{Cov}\left(y_{i j k}, z_{i j k}\right)\right],
$$

where

$$
\operatorname{Cov}\left(y_{i j k}, z_{i j k}\right)=\frac{\left[\sum_{k=1}^{a} x_{i j k} y_{i j k}-\frac{\left(\sum_{k=1}^{a} y_{i j k}\right)\left(\sum_{k=1}^{a} x_{i j k}\right)}{a}\right]}{a-1} .
$$

\section{Estimating Passage Performance}

\section{Passage Abundance}

The individual values of $\hat{S}_{g}$ estimate smolt passage through the gth spillbay $(g=1, \ldots, H)$. If there is desire to estimate passage abundance across two or more spillbays, then an estimate of total passage would be calculated as 


$$
\hat{S}_{T}=\sum_{g=1}^{H} \hat{S}_{g}
$$

where $\hat{S}_{g}=$ estimated smolt passage though the gth spillbay $(g=1, \ldots, H)$. The variance of $\hat{S}_{T}$ would be estimated by the quantity

$$
\widehat{\operatorname{Var}}\left(\hat{S}_{T}\right)=\sum_{g=1}^{H} \widehat{\operatorname{Var}}\left(\hat{S}_{g}\right) \text {. }
$$

\section{Passage Efficiency}

Passage efficiency at the gth spillbay is defined as

$$
\mathrm{PE}_{g}=\frac{S_{g}}{\sum_{i=1}^{H} S_{i}}
$$

in other words, the fraction of smolts that pass through the gth spillbay among $\mathrm{H}$ bays. Passage efficiency at a single spillbay can be estimated by

$$
\widehat{\mathrm{PE}}_{g}=\frac{\hat{S}_{g}}{\sum_{i=1}^{H} \hat{S}_{i}}
$$

with associated variance estimator

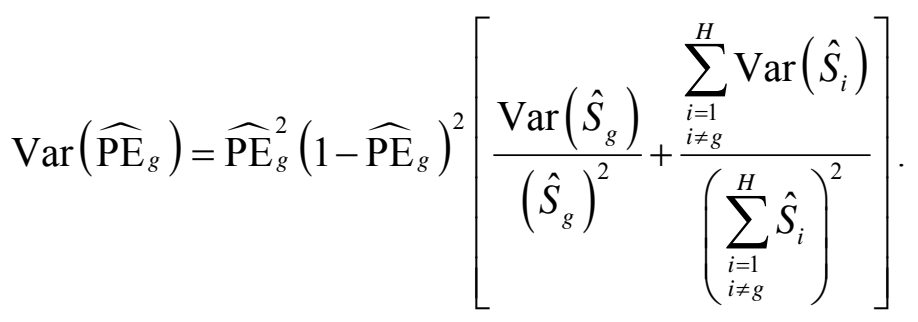

Passage efficiency for a group of spillbays $i, \ldots, h$ from among a total of $\mathrm{H}$ bays can be estimated by

$$
\widehat{\mathrm{PE}}_{1, h}=\frac{\sum_{i=1}^{h} \hat{S}_{i}}{\sum_{i=1}^{H} \hat{S}_{i}}
$$

with associated variance estimator

$$
\widehat{\operatorname{Var}}\left(\widehat{\mathrm{PE}}_{1, h}\right)=\widehat{\mathrm{PE}}_{1, h}^{2}\left(1-\widehat{\mathrm{PE}}_{1, h}\right)^{2}\left[\frac{\sum_{i=1}^{h} \widehat{\operatorname{Var}}\left(\hat{S}_{i}\right)}{\left(\sum_{i=1}^{h} \hat{S}_{i}\right)^{2}}+\frac{\sum_{i=h+1}^{H} \widehat{\operatorname{Var}}\left(\hat{S}_{i}\right)}{\left(\sum_{i=h+1}^{H} \hat{S}_{i}\right)^{2}}\right] .
$$




\section{Smolt Density}

Performance at a spillbay can be expressed as smolt passage per unit water; in which case, the passage density can be estimated at the gth spillbay by

$$
\hat{D}_{g}=\frac{\hat{S}_{g}}{F_{g}},
$$

where $F_{g}=$ total flow volume through spillbay g over the period passage is estimated. Fish passage density has the associated variance estimator

$$
\widehat{\operatorname{Var}}\left(\hat{D}_{g}\right)=\frac{1}{F_{g}^{2}} \cdot \widehat{\operatorname{Var}}\left(\hat{S}_{g}\right) \text {. }
$$

For multiple spillbays, fish density would be estimated by

$$
\hat{D}_{1, h}=\frac{\sum_{i=1}^{h} \hat{S}_{i}}{\sum_{i=1}^{h} F_{i}}
$$

with associated variance estimator

$$
\widehat{\operatorname{Var}}\left(\hat{D}_{1, h}\right)=\frac{1}{\left(\sum_{i=1}^{h} F_{i}\right)^{2}} \cdot \sum_{i=1}^{h} \widehat{\operatorname{Var}}\left(\hat{S}_{i}\right) .
$$

\section{Spill Effectiveness}

Spill effectiveness at bay g relative to the other spillbays $1, \ldots, H$ can be estimated by the expression

$$
\widehat{\mathrm{SE}}_{g}=\frac{\left[\frac{\hat{S}_{g}}{\sum_{i=1}^{H} \hat{S}_{i}}\right]}{\left[\frac{F_{g}}{\sum_{i=1}^{H} F_{i}}\right]}=\frac{\widehat{\mathrm{PE}}_{g}}{\left[\frac{F_{g}}{\sum_{i=1}^{H} F_{i}}\right]}
$$

with associated variance estimator

$$
\widehat{\operatorname{Var}}\left(\widehat{\mathrm{SE}}_{g}\right)=\left(\frac{\sum_{i=1}^{H} F_{i}}{F_{i}}\right)^{2} \cdot \widehat{\operatorname{Var}}\left(\widehat{\mathrm{PE}}_{g}\right) \text {. }
$$

Spill effectiveness for a group of spillbays $i=1, \ldots, h$ from among a total of $\mathrm{H}$ bays can be estimated by the quantity 


$$
\widehat{\mathrm{SE}}_{1, h}=\frac{\left[\begin{array}{l}
\sum_{i=1}^{h} \hat{S}_{i} \\
\sum_{i=1}^{H} \hat{S}_{i}
\end{array}\right]}{\left[\frac{\sum_{i=1}^{h} F_{i}}{\sum_{i=1}^{H} F_{i}}\right]}=\frac{\widehat{\mathrm{PE}}_{1, h}}{\left[\frac{\sum_{i=1}^{h} F_{i}}{\sum_{i=1}^{H} F_{i}}\right]}
$$

with associated variance estimator

$$
\widehat{\operatorname{Var}}\left(\widehat{\mathrm{SE}}_{1, h}\right)=\left[\frac{\sum_{i=1}^{H} F_{i}}{\sum_{i=1}^{h} F_{i}}\right]^{2} \cdot \widehat{\operatorname{Var}}\left(\widehat{\mathrm{PE}}_{1, h}\right) .
$$


Appendix B

Spatial Expansions 
Hydroacoustic Evaluation of Juvenile Salmonid Passage at The Dalles Dam Spillway, 2006 


\section{Appendix B}

\section{Spatial Expansions}

We calculated effective beam angles by flow increments (variable called FLOWBIN). Hourly data on mean flow (KCFSBAR) were used to categorize the data as follows:

IF KCFSBAR GE 18 THEN FLOWBIN='HIGH ';

IF KCFSBAR GE 15 AND KCFSBAR LT 18 THEN FLOWBIN='MEDHIGH';

IF KCFSBAR GE 12 AND KCFSBAR LT 15 THEN FLOWBIN='MEDLOW ';

IF KCFSBAR LT 12 AND KCFSBAR GT 0 THEN FLOWBIN='LOW ';

IF KCFSBAR $=0$ THEN FLOWBIN $=$ 'OFF'.

We applied detection curve coefficients using the results by FLOWBIN from the detectability model DETECTABILITY.EXE output in the Bean Width spreadsheet of the DETECTINPUT.XLS workbook. The effective beam width (E_ANGLE) equation separately for spring and summer were:

For spring,

IF FLOWBIN='HIGH' then E_ANGLE $=0.00997377525676395^{*}$ Mid_Range**4 -

$0.260254444590633 *$ Mid_Range**3 $+2.15320785812567 *$ Mid_Range**2 -

$6.78201773690925^{*}$ Mid_Range +12.5399996439617 ;

IF FLOWBIN='MEDHIGH' then E_ANGLE $=-0.00736451142039899 *$ Mid_Range**4 +

$0.170474962245244 *$ Mid_Range**3 -1.19857679012218*Mid_Range**2 +

2.47585714984149*Mid_Range +5.50083283583318;

IF FLOWBIN='MEDLOW' then E_ANGLE $=-0.00466346101605263 *$ Mid_Range**4 +

$0.13402776469903 *$ Mid_Range**3 -1.17334050065156*Mid_Range**2 +

3.52054347923405*Mid_Range +3.23416717847184;

IF FLOWBIN='LOW' then E_ANGLE $=-0.0187135783386677 *$ Mid_Range**4 +

$0.366106261277073 *$ Mid_Range**3 -2.41329988580209*Mid_Range**2 +

$6.16172906865247^{*}$ Mid_Range +1.20749974250784 ;

For summer,

IF FLOWBIN='HIGH' then E_ANGLE=-0.00727709853426849*Mid_Range**4 + $0.166659880930267 *$ Mid_Range**3 -1.14904291406797*Mid_Range**2 + (2.28050523195147)*Mid_Range +4.84583312273021 ;

IF FLOWBIN='MEDHIGH' then E_ANGLE $=0.00101252987390347 *$ Mid_Range**4 + $0.00144035059440725 *$ Mid_Range**3 $-0.15386501163037 *$ Mid_Range**2 + $0.351010023111909 *$ Mid_Range +6.27749987443286 ;

IF FLOWBIN='MEDLOW' then E_ANGLE $=0.00510926555086678 *$ Mid_Range**4 $0.0978952977855527 *$ Mid_Range**3 $+0.640511367843416 *$ Mid_Range**2 $2.05057500449833 *$ Mid_Range +8.89750003814696 ;

IF FLOWBIN='LOW' then E_ANGLE=0.00461684115283135*Mid_Range**4 - 


$$
\begin{aligned}
& 0.0946649114753992 * \text { Mid_Range } * * 3+0.63902822171613 * \text { Mid_Range } * * 2- \\
& 1.89820506504179 * \text { Mid_Range }+8.88583334287007
\end{aligned}
$$

Each individual fish track was extrapolated spatially as follows:

$$
\text { Expanded Fish }=\text { FISH*3.048/(TAN(ANGLE/2*3.1416/180)*Mid_Range*2), }
$$

where, TAN returns the tangent of the half angle (ANGLE/2) expressed in radians (*Pi/180). Two times the TAN of the half angle times range is the diameter of the beam at that range (Mid_Range) and $3.048 \mathrm{~m}$ is the width of the $1 / 5$ sampling section at the spillway in 2006 . 